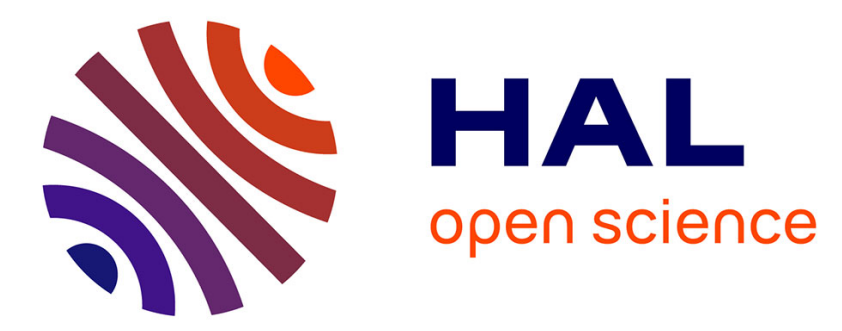

\title{
The endemic 'sugar canes' of Madagascar (Poaceae, Saccharinae: Lasiorhachis) are close relatives of sorghum
}

Maria Vorontsova, Guillaume Besnard, Jacqueline Razanatsoa, Jan Hackel

\section{To cite this version:}

Maria Vorontsova, Guillaume Besnard, Jacqueline Razanatsoa, Jan Hackel. The endemic 'sugar canes' of Madagascar (Poaceae, Saccharinae: Lasiorhachis) are close relatives of sorghum. Botanical Journal of the Linnean Society, 2020, 192 (1), pp.148-164. 10.1093/botlinnean/boz067 . hal-02988767

\section{HAL Id: hal-02988767 https://hal.science/hal-02988767}

Submitted on 23 Apr 2021

HAL is a multi-disciplinary open access archive for the deposit and dissemination of scientific research documents, whether they are published or not. The documents may come from teaching and research institutions in France or abroad, or from public or private research centers.
L'archive ouverte pluridisciplinaire HAL, est destinée au dépôt et à la diffusion de documents scientifiques de niveau recherche, publiés ou non, émanant des établissements d'enseignement et de recherche français ou étrangers, des laboratoires publics ou privés. 


\section{LINNEAN BOTANICAL SOCIETY Journal ofthen scoity}

\section{The endemic "sugar canes" of Madagascar (Poaceae, Saccharinae: Lasiorhachis) are close relatives of sorghum}

\begin{tabular}{|r|l|}
\hline Journal: & Botanical Journal of the Linnean Society \\
\hline Manuscript ID & BOTJLS-Mar-2019-3303-ART.R2 \\
\hline Manuscript Type: & Original Article \\
\hline Author: & 19 -Aug-2019 \\
\hline Complete List of Authors: & $\begin{array}{l}\text { Vorontsova, Maria; Royal Botanic Gardens, Kew, HLAA } \\
\text { Besnard, Guillaume; CNRS, Université Paul Sabatier, EDB, Laboratoire } \\
\text { Evolution \& Diversité Biologique } \\
\text { Razanatsoa, Jacqueline; Tsimbazaza Botanical and Zoological Park and } \\
\text { Research Centre, Département Flore } \\
\text { Hackel, Jan; Royal Botanic Gardens, Kew, HLAA; CNRS, Université Paul } \\
\text { Sabatier, EDB, Laboratoire Evolution \& Diversité Biologique }\end{array}$ \\
\hline Keywords: & $\begin{array}{l}\text { Madagascar < Geography, phylogenetic relationships < Systematics, } \\
\text { phylogenetics < Systematics, nuclear markers < Genetics, chloroplast } \\
\text { DNA < Genetics, Poaceae < Taxa, Taxonomy, Evolution }\end{array}$ \\
\hline & \\
\hline
\end{tabular}

\section{SCHOLARONE Manuscripts}


Malagasy Lasiorhachis

The endemic "sugar canes" of Madagascar (Poaceae, Saccharinae: Lasiorhachis) are close relatives of sorghum

Running title: Malagasy Lasiorhachis

MARIA S. VORONTSOVA ${ }^{1, *}$, GUILLAUME BESNARD ${ }^{2}$, JACQUELINE RAZANATSOA ${ }^{3}$ and JAN HACKEL ${ }^{1,2}$

${ }^{1}$ Comparative Plant and Fungal Biology, Royal Botanic Gardens, Kew, Richmond, Surrey TW9 3AB, UK ${ }^{2}$ CNRS, Université de Toulouse, IRD, UMR5174, EDB (Laboratoire Évolution \& Diversité Biologique), 118 route de Narbonne, 31062 Toulouse, France

${ }^{3}$ Herbier, Département Flore, Parc Botanique et Zoologique de Tsimbazaza, BP 4096, Antananarivo 101, Madagascar

*Corresponding author. E-mail: $\underline{\text { m.vorontsova@kew.org. }}$ 
Malagasy Lasiorhachis

Crop wild relatives are important but often poorly known. This is the case for subtribe Saccharinae (Poaceae: Andropogoneae) which includes sugarcane (Saccharum) and sorghum (Sorghum). We present a phylogenetic and taxonomic account of the Malagasy endemic genus Lasiorhachis, previously included in Saccharum. New plastome and nuclear sequences were assembled from genome skimming data. Phylogenetic analyses of whole plastomes place Lasiorhachis as sister to Sorghum and only distantly related to the interbreeding Saccharum complex. This is also supported by analyses of nuclear ITS and partial assemblies for eight low-copy regions. Some nuclear regions suggest that Lasiorhachis is closer to Sorghum section Sorghum than other Sorghum spp. sometimes segregated as Vacoparis. We present a full taxonomic treatment of Lasiorhachis with an identification key, synonymy, typification, descriptions, drawings, and a distribution map of the three species, all endemic to the central highlands of Madagascar. Lasiorhachis species occupy contrasting ecological niches and at least one of them, L. viguieri, has significance for ecosystem function. As crop wild relatives of sorghum, Lasiorhachis species should be included in germplasm collections.

KEYWORDS

Andropogoneae - crop wild relative - grass - lectotype - phylogenetics - Malagasy - nuclear genes - plastome - Saccharum - shotgun sequencing - taxonomy - typification 
Malagasy Lasiorhachis

\section{INTRODUCTION}

The value of wild relatives of crop species is increasingly acknowledged. Besides their interest for comparative studies of domestication and traits related to productivity or stress resistance, they provide an important genetic reservoir that may be harnessed through traditional breeding or genetic engineering for sustainable agriculture (Brozynska, Furtado \& Henry, 2016; CastañedaÁlvarez et al., 2016; Dempewolf et al., 2017; Zhang et al., 2017). In many cases however, these wild relatives are insufficiently known, rare, narrow in distribution or threatened, and they are often not represented in germplasm collections; poorly resolved taxonomy of many groups impedes targeted collection, curation and conservation of crop wild relatives (Castañeda-Álvarez et al., 2016).

Poaceae subtribe Saccharinae [Panicoideae: Andropogoneae; including Sorghinae as defined by Kellogg (2015) and Soreng et al. (2017)] comprise important food and biofuel crops, valued for their rapid growth in tropical and subtropical climates, partly due to their $\mathrm{C}_{4}$ photosynthetic pathway (Kellogg, 2015). Outstanding among them is sugarcane, i.e. the three cultivated species of Saccharum L. and their commercial hybrid cultivars. In 2017, the world produced 1.8 billion tonnes of sugarcane, far outstripping any other single crop (FAOSTAT, 2019). Sorghum, Sorghum bicolor (L.) Moench, is an important grain and fodder crop with $>57$ million tonnes annual production (FAOSTAT, 2019). Species of Miscanthus Andersson, which also grow in cooler regions, have attracted increasing interest due to their potential use as second-generation biofuel (Heaton, Dohleman \& Long, 2008; Brosse et al., 2012; Sacks et al., 2013; Zhuang et al., 2013). Underlining this importance as crops, the genome sequence of S. bicolor was made available in 2009 (Paterson et al., 2009) and was followed more recently by M. sinensis Andersson (Energy Biosciences Institute and Joint Genome Institute, 2017) and the highly polyploid genome of sugarcane (Garsmeur et al., 2018), "probably the most complex of all plant crops" (Aitken, Berkman \& Rae, 2016). 
Malagasy Lasiorhachis

Andropogoneae, including Saccharinae, have been recognized as among the most morphologically complex groups of grasses (Clayton \& Renvoize, 1986). The evolutionary history of Saccharinae is just beginning to be untangled, and the taxonomic delimitation is being reconsidered as our understanding of the evolutionary history of the group develops. Phylogenetic evidence for their monophyly is contradictory (Hodkinson et al., 2002; Kellogg, 2013; Hawkins et al., 2015; Saarela et al., 2018), and there are no obvious morphological synapomorphies (Kellogg, 2015). The classification by Kellogg (2015) included 16 genera, with 177 species, whereas Soreng et al. (2017) accepted 26 genera.

Several genera of Saccharinae, including some potentially allied to Saccharum, e.g. Eulalia Kunth, are highly polyphyletic (Kellogg, 2015). Saccharum s.s. includes only six species, and several others traditionally included are either closer to Miscanthus or entirely unrelated (Hodkinson et al., 2002; Kellogg, 2013, 2015; Evans et al. 2019). The Saccharum complex, as originally defined for plant breeders by Mukherjee (1954) and expanded by Daniels \& Daniels (1975), included Saccharum, Erianthus Michx. section Ripidium Henrard, Miscanthus and Sclerostachya (Andersson ex Hackel) A.Camus and Narenga Bor (both now part of Miscanthus). Erianthus section Ripidium is now treated as a separate genus, Tripidium H.Scholz, not directly related to either Saccharum or Erianthus Michx. (Welker et al., 2015; Evans at al., 2019; Welker et al., 2019). Evans et al. (2019) updated the definition of the Saccharum complex to include all groups interbreeding in the wild: Miscanthus, Miscanthidium Stapf, Saccharum and New World Erianthus. Outside this complex, Sorghum is polyphyletic, and Sarga Ewart now includes around half of the former Sorghum spp. (Spangler, 2003; Hawkins et al., 2015; Kellogg, 2015). Reticulate evolution with frequent allopolyploidization, as in many other Andropogoneae (Estep et al., 2014), probably characterizes Saccharinae and leads to genes with diverging histories (Kellogg, 2013; Welker et al., 2015). Identifying and preserving wild relatives of sugarcane, sorghum and Miscanthus is therefore non-trivial. For example, the World Collection of Sugarcane and Related Grasses (WCSRG at the USDA-ARS Subtropical Horticulture 
Malagasy Lasiorhachis

Research Station in Miami, Florida) includes a wide array of species of Saccharinae for which relationships are not yet fully understood (Todd et al., 2017).

Species of Saccharinae endemic to Madagascar remain poorly known and have so far not been included in germplasm collections due to the sparseness of scientific links and difficulties in accessing material. The first awnless endemic species was described by Hackel (1885) as Andropogon hildebrandtii Hack. and placed in the new Andropogon section Lasiorhachis Hack., named after the soft woolly texture of its synflorescence. Andropogon section Lasiorhachis was raised to the rank of subgenus (Hackel, 1889) and then to genus (Stapf, 1927). Stapf (1927) noted that "the structure of the panicle and of the spikelets has more in common with Sorghum than with any other genus". The other two species have awns and were originally described in Erianthus (Camus, 1924), moved to Miscanthidium (Camus, 1959) and brought together with the awnless L. hildebrandtii (Hack.) Stapf in Lasiorhachis (Hack.) Stapf by Bosser (1968). The genus was then incorporated into Saccharum by Clayton (1981), even though "its true position lies between Saccharum and Hemisorghum" (Clayton, 1981). The first DNA sequence data for Lasiorhachis were not published until Hackel et al. (2018): the plastid markers $n d h F, r b c L$ and trnk-matK placed the three species, with Eulalia villosa (Spreng.) Nees, close to Sorghum, but with weak support. A plastome sequence of the type species $L$. hildebrandtii was published by Piot et al. (2018) and strongly supported the species as sister to Sorghum bicolor.

We present an account of Lasiorhachis, comprising three species endemic to Madagascar that were previously classified in Saccharum, but are now accepted as a separate genus again (Kellogg, 2015; Soreng et al., 2017; Vorontsova et al., 2018). A full taxonomic treatment is given alongside new plastome and nuclear genetic data to reassess their phylogenetic position. We confirm that Lasiorhachis is the sister genus of Sorghum, which helps further clarify the taxonomy of Saccharinae and brings new relevance to this genus of crop wild relatives.

MATERIAL AND METHODS 
Malagasy Lasiorhachis

\section{ACCESSIONS AND TAXONOMY}

Collection trips were conducted across Madagascar during the period $2011-2018$. Ten occurrences of Lasiorhachis were seen in the wild and collections were made (Fig. 1). Cultivation of Lasiorhachis perrieri (A.Camus) Bosser was attempted at the Parc Botanique et Zoologique de Tsimbazaza, but without success. A full taxonomic analysis of the 76 collections held at the $K, P$ and TAN herbaria was carried out. Descriptive morphological terms such as "inflorescence" are used for recognition and communication purposes only, and further research will be required to align these to developmentally correct terminology such as "synflorescence", as reviewed by Kellogg (2015). This study focuses on macromorphological characters and does not attempt to examine micromorphology or anatomy.

\section{SEQUENCING AND MARKER ASSEMBLY}

Genomic DNA from two Lasiorhachis specimens (L. hildebrandtii LRK2008 and L. perrieri NOP140) was extracted and shotgun-sequenced on a HiSeq machine as described in Besnard et al. (2013), producing 125 -bp paired-end reads. The full L. hildebrandtii plastid genome (plastome) has been published by Piot et al. (2018), and we assembled the plastome of $L$. perrieri as described therein. We also assembled partial nuclear ribosomal DNA ( $n$ rDNA) containing the internal transcribed spacer regions (ITS) for both accessions. For this, reads were mapped to $S$. bicolor $5.8 \mathrm{~S}$ nrDNA sequence (MH762138.1) in Geneious v. 8.0.5 (Biomatters Ltd.), using the built-in mapping algorithm with default parameters, and mapping again to a $75 \%$ majority consensus sequence for ten iterations. Coverage for nrDNA was $>1000 x$ in both accessions. Partial coding sequences (CDS) were further assembled for eight low-copy nuclear regions for which sufficient homologues from Andropogoneae were available in GenBank: the aberrant panicle organization 1 gene (apo1); the DELLA-encoding protein gene dwarf8 (dwarf8); floricaula/leafy-like (floricaula); the granule-bound starch synthase 1 gene (GBSSI or waxy); erect panicle 2 exons 7 and 8 (ep2-7 and ep2-8); the phytochrome B gene (phyB); and retarded palea 1 (rep1). For assembly, reads were mapped to the exon sequences from 
Malagasy Lasiorhachis

the S. bicolor genome (GCF_000003195.3) in Geneious. A 75\% majority consensus sequence was then called and sites with total base phred quality $<30$ or not covered were coded as N. Assembled exons were finally merged, not using exons with $>50 \%$ ambiguous bases. Mean coverage per exon ranged from 0.9 to $4.7 \times$. The sequencing reads have been submitted to the Sequence Read Archive (BioProject No. [to be added]), assembled plastome and nrDNA sequences to GenBank (accession numbers MF563371.1 and [to be added], and [to be added] and [to be added], respectively), and the incomplete low-copy gene assemblies are available as supplementary file XX.

\section{PhyLOGENETIC ANALYSIS}

The plastome sequences were combined with 54 other full plastomes, including representatives of Andropogoneae selected from recent studies (Burke et al., 2016; Arthan et al., 2017) and all plastomes of Eulalia, Miscanthus, Miscanthidium, Saccharum, Sarga and Sorghum that are available on GenBank. After excluding the second inverted repeat region, they were aligned using the default MAFFT v. 7.407 (Katoh \& Standley, 2013) algorithm. CDS and non-coding regions were extracted from the alignment and phylogenetic trees inferred separately using Bayesian estimation in MrBayes v. 3.2.6 (Ronquist \& Huelsenbeck, 2003; Altekar et al., 2004) with a GTR+ץ substitution model, running two analyses with four chains until the standard deviation of splits was $<0.01$. We also reestimated a phylogeny based on ndhF-rbcL-trnk/matK for Saccharinae and selected outgroup taxa. For this, we combined the data used by Hackel et al. (2018) with the respective regions extracted from the full plastomes, aligned each marker set using the MAFFT G-INS-i algorithm, trimmed alignment ends with $>90 \%$ missing data and concatenated the three alignments. A phylogenetic tree was produced from the concatenated alignment using MrBayes as described above, partitioning by gene. We also compared topologies with the monophyly of Lasiorhachis constrained or not via a likelihood ratio test in RAxML v. 8.2.12 for the $n d h F-r b c L-t r n k / m a t K$ alignment. Finally, for ITS and the low-copy nuclear genes, we retrieved homologous sequences for Andropogoneae via blastn searches (Camacho et al., 2009) against GenBank, retaining only the longest matching sequence per 


\section{Malagasy Lasiorhachis}

NCBI taxon for ITS and the longest among identical sequences for the low-copy genes. Each set of sequences was then aligned with the Lasiorhachis assemblies using MAFFT-G-INS-i, alignment ends trimmed and trees inferred using MrBayes as described above. We used Arthraxon P.Beauv. for rooting the plastome tree given its early-diverging position in Andropogoneae s.s. based on the plastome analyses of Arthan et al. (2017). Sequences of Arthraxon were not available for all nuclear markers and we chose Arundinella Raddi, which was consistently available, as a less closely related lineage outside Andropogoneae s.s. for rooting.

\section{RESULTS}

\section{TAXONOMY}

A visual examination of specimens, spikelet dissections and living plants suggested the presence of three clearly distinct species with different morphologies and ecological niches in Madagascar. None of these has been recorded outside the island. None of the previously published treatments of these species by Bosser $(1968,1969)$ and Clayton $(1981)$ included parallel descriptions and identification keys. The first full taxonomic treatment of Lasiorhachis is presented below.

\section{PHYLOGENETIC ANALYSIS}

Plastome sequences strongly supported L. perrieri NOP140 and L. hildebrandtii LRK2008 as sister to each other and placed both as sister to Sorghum (represented by S. bicolor and S. mekongense A.Camus), with Sarga timorensis (Kunth) Spangler being the next closest relative (Figs 2, S1). Lasiorhachis thus fell in Andropogoneae subtribe Saccharinae (fide Kellogg, 2015, Soreng et al., 2017) but was clearly distinct from the Saccharum complex. Support was generally higher for the tree inferred from non-coding parts of the plastome alignment, but CDS supported the same position for Lasiorhachis and recovered most of the other clades. The plastid ndhF-rbcL-trnk/matK tree did not resolve relationships among Sarga, Sorghum and Lasiorhachis, despite more species being sampled (Fig. 3). It also placed two accessions of Eulalia villosa in Lasiorachis with weak 
Malagasy Lasiorhachis

support; a likelihood ratio test, however, did not reject the monophyly of Lasiorhachis compared to an unconstrained topology $(p=0.23, \log L$ difference -0.005$)$.

The trees for ITS and the eight low-copy regions, containing between 47 and 320 tips, received only weak support for the backbone of Andropogoneae (Figs 3, S1 A-I). However, all trees grouped Lasiorhachis with Sorghum spp., distinct from the species of the Saccharum complex and a Sarga clade (= Sorghum sections Stiposorghum and Parasorghum). In four trees (apo1, dwarf8, ep2-7, ep28) in which S.orghum laxiflorum F.M.Bailey and S. macrospermum E.D.Garber (Sorghum sections Chaetosorghum and Heterosorghum, respectively) are represented, their sequences are placed sister to or paraphyletic with respect to Lasiorhachis (Fig. 4 A, B, D, E), which is thus closer to a clade corresponding to Sorghum section Sorghum [Sorghum arundinaceum (Desv.) Stapf, S. bicolor, S. halepense (L.) Pers. and/or S. propinquum (Kunth) Hitchc.; also including sequences identified as Polytrias indica (Houtt.) Veldkamp in rep1; Fig. S2 I]. Cleistachne sorghoides Benth. was placed with either Sarga or Sorghum. The seven nuclear trees that included Eulalia villosa (ITS, dwarf8, ep2-7, ep2-8, GBSSI, phyB ando rep1) placed it clearly distant from Lasiorhachis, Sarga and Sorghum.

\section{DISCUSSION}

The phylogenetic analysis presented here confirms Lasiorhachis spp. as close relatives of Sorghum, as recognized by Stapf (1927). Lasiorhachis is closer to Sorghum s.s. than the species segregated from it as Sarga (Spangler, 2003), and it is clearly distinct from sugarcane and its relatives in the Saccharum complex. This confirms the result of Piot et al. (2018), who included only L. hildebrandtii in their plastome analysis. A coalescent analysis of nuclear genome-wide markers also supports $L$. hildebrandtii as sister to S. bicolor and suggests a dominant nuclear signal for this position (Bianconi et al., unpublished data). Limited available nuclear sequence data for S. laxiflorum and S. macrospermum included in our analysis suggest that these species (segregated as Vacoparis Spangler; Spangler, 2003) may be more distant from Sorghum s.s. (i.e. Sorghum section Sorghum) than Lasiorhachis. Paraphyly of sequences of these two species with regard to Lasiorhachis may 
Malagasy Lasiorhachis

indicate an allopolyploidy event before the origin of Lasiorhachis and Sorghum. The single known chromosome count in Lasiorhachis is $2 n=20$ (recorded on the herbarium specimen Tateoka 3514, P02643315 of L. hildebrandtii), suggesting that it is diploid based on the Andropogoneae base count of $x=10$ (Kellogg, 2015); due to the shallow sequencing and our assembly method, potential paralogous genes resulting from any allopolyploidy could not be distinguished.

Taken together, the results strongly support Lasiorhachis as sister to Sorghum s.s. (= Sorghum section Sorghum) and may warrant the recognition of Vacoparis as separate genus. It is also possible that following more comprehensive analyses Lasiorhachis may become part of the broader Sorghum. Additional data from all species of Sorghum and Lasiorhachis, especially from more variable plastid markers (or entire plastomes), are needed. Clearly, plastid $n d h F+r b c L+t r n K / m a t K$ are insufficient to resolve relationships (see Fig. 3), and we expect the placement of Eulalia villosa in Lasiorhachis in the three-gene tree to change with more data, especially since all nuclear trees including this species place it in a distant position.

Macromorphological characters traditionally used in keys and taxonomic treatments do not provide enough data for a clear differentiation of clades or genera in Lasiorhachis and its relatives, as evidenced by the multiple alternative taxon delimitations discussed above. The variability in male and female expression and development, of both sessile and pedicellate spikelets, were cited as a distinguishing characteristic of Lasiorhachis by Stapf (1927) and Bosser (1968), but it does also occur across Andropogoneae as pointed by Clayton (1981) and Kellogg (2015). Hackel $(1885,1889)$ described L. hildebrandtii as having glabrous lodicules and an apically pilose ovary, and Stapf (1927) corrected these to apically pilose lodicules and a glabrous ovary; we have also recorded pilose lodicules and a glabrous ovary, although anatomical data needs confirmation through a more detailed study. This study did not confirm the presence of the ovary appendage in L. hildebrandtii recorded by Watson, Macfarlane \& Dallwitz (1992 onwards) and Kellogg (2015): this could be due to 
Malagasy Lasiorhachis

our focus on macromorphology and a lack of detailed micromorphological examination. Critical micromorphological and anatomical study of fresh material is still necessary for all three species.

Functional traits of dominant $\mathrm{C}_{4}$ Poaceae determine ecosystem function in the subtropical grasslands and savannas of Madagascar (Solofondranohatra et al., 2018), which cover at least 65\% of the land area (Moat \& Smith, 2007). Lasiorhachis makes a non-trivial contribution to ecosystem function: the most abundant species, L. viguieri (A.Camus) Bosser, dominates flammable rocky grasslands alongside Panicum andringitrense A.Camus at c. $2200 \mathrm{~m}$ elevation on the granite plateau of Andringitra National Park (site 6; Vorontsova et al., 2016). Its woody rhizomes and thick culm bases persist during fires and form the ground cover in several highland ecosystems (Vorontsova M.S., pers. obs.). Lasiorhachis hildebrandtii occupies a contrasting shady niche and is one of the few $\mathrm{C}_{4}$ plants to be found under forest canopy, at somewhat lower elevations. The niche of Lasiorhachis perrieri is different again: the larger size of its tussocks restricts its habitats to those with a ready source of running water. Occurrence of Sorghum in Madagascar is still poorly recorded, but there are both native and introduced, wild, food and fodder species; these tend to occupy habitats at lower elevations than Lasiorhachis, often found close to human dwellings and in disturbed areas.

Divergence in morphology and ecological niche in Lasiorhachis suggests a long evolutionary history. The median stem age estimate of Hackel et al. (2018) for the two Lasiorhachis clades of between 2.5-4.0 Mya was modelled on a more poorly resolved tree topology. Bianconi et al. (unpublished data), using genome-level data, dated the median split between S. bicolor and L. hildebrandtii at 4 Mya under a "younger" calibration scenario. This suggests that the diversification of Lasiorhachis in Madagascar occurred during the Pleistocene or, potentially, the Late Miocene. Although the majority of the grass flora of Madagascar probably dispersed from Africa, Lasiorhachis was estimated by Hackel et al. (2018) to have an Asian-Australasian origin, albeit based on a weakly supported topology. If the relationship of the Australasian "Vacoparis" as sister to Malagasy Lasiorhachis and Asian-African Sorghum s.s. proves to be correct, this would support an Australo- 
Malagasy Lasiorhachis

Asian origin of the group followed by dispersal to Africa and Madagascar. Any conclusion on the origin and timing of Lasiorhachis and its diversification will require studies at the population level as well as a better understanding of the whole of the enigmatic Saccharinae.

No accessions of Lasiorhachis have been successfully cultivated to date, despite of their horticultural potential due to their beautiful inflorescence colours: snow-white in L. hildebrandtii, golden brown in L. perrieri and a vivid pink-purple in L. viguieri. No seed collections have been made. No tests for potentially useful alleles have been carried out. As well as providing a missing piece of the evolution puzzle of Saccharinae, Lasiorhachis remains a mysterious knowledge gap in its own right.

\section{TAXONOMIC TREATMENT}

Lasiorhachis (Hack.) Stapf in Hooker's Icon. PI. 32: t. 3124. 1927 as 'Lasiorrhachis' ミ Andropogon section Lasiorhachis Hack. in Flora 68: 142. 1885 三 Andropogon subgenus Lasiorhachis (Hack.) Hack. in Monogr. Phan. [A.DC. \& C.DC.] 6: 471. 1889.

Type: Lasiorhachis hildebrandtii (Hack.) Stapf (Andropogon hildebrandtii Hack.).

Coarse long-lived densely tufted perennials with short thick woody rhizomes and erect flowering culms. All leaves basal. Ligule membranous to coriaceous. Auricles absent or deltoid. Leaf blades thick, linear to narrow-lanceolate, with a pronounced white midrib. Inflorescences silky terminal panicles with primary and secondary branching from the main culm. Spikelets paired. Internodes apically cupulate. Internodes and pedicels villous. Callus truncate. Sessile spikelet lower floret sterile, upper floret hermaphrodite. Glumes chartaceous to coriaceous, convex. Upper lemma bilobed, ciliate at the apex, with or without an awn. Lodicules with apical hairs. Anthers three. Pedicelled spikelets the same as sessile spikelets and hermaphrodite, or somewhat reduced in size and male. Sometimes the pedicel and the pedicelled spikelet reduced or absent on some branches. 
Malagasy Lasiorhachis

to be stored primarily in the woody rhizomes and the lowermost culm internodes. Lasiorhachis viguieri frequently loses aboveground biomass to fires; leaves and culms regrow after fire from lower parts of the plant. No signs of burning were noted on L. hildebrandtii or L. perrieri.

The presence, size, and reproductive functionality of the pedicelled spikelet varies between different parts of the inflorescence and between plants. Complete absence of the pedicellate spikelet is rare and has only been noted in some lowermost inflorescence branches of $L$. hildebrandtii. The most common condition is a male pedicellate spikelet (L. perrieri) or a bisexual pedicellate spikelet (L. hildebrandtii, L. viguieri). The dispersal unit is most commonly a single spikelet which detaches as the spikelet callus is separated from the cupular apex of the internode. When the pedicellate spikelet is male, sterile or absent, the sessile hermaphrodite spikelet often falls off together with its pedicel and the pedicellate spikelet. It also seems common for a section of an inflorescence branch with c. 2-20 spikelets to detach as a whole. The relative roles of the indumentum (thick in all species) and the awns (present in two of three species) in seed dispersal are not clear. No seed dispersal agents are known.

KEY TO LASIORHACHIS:

1. Inflorescences snow-white in colour; inflorescence branches loose and pendent; awns absent.

1. L. hildebrandtii

1. Inflorescences tinged brown or pink or purple; inflorescence branches erect; awns present.. 2

2. Flowering culms 1.5-2.0 m tall; inflorescences tinged brown; sessile spikelets 3.0-4.0(-4.5) mm long

2. L. perrieri

2. Flowering culms 0.50-1.15(-1.45) m tall; inflorescences tinged pink or purple; sessile spikelets (56-9 $\mathrm{mm}$ long 3. L. viguieri 
Malagasy Lasiorhachis

1. Lasiorhachis hildebrandtii (Hack.) Stapf in Hooker's Icon. PI. 32: t. 3124. 1927 E Andropogon hildebrandtii Hack. Flora 68: 141. 1885 三 Saccharum hildebrandtii (Hack.) Clayton Kew Bull. 35(4): 818. 1981. Type: MADAGASCAR, Antananarivo, Andrangolaoka, Nov 1880, J.M.Hildebrandt 3755 (Lectotype designated here: W [W1916-0028387] (photograph!), isolectotypes: JE [JE00012628, JE00012629] (photograph!), K [K000244592]!, P [P00450367, P00450368, P00450369]!, W [W18890039830, W1916-0028386] (photograph!)).

Tufted perennial 0.6-1.5(-2.0) m. Flowering culm 2.5-5.0 mm diameter at base. Nodes dark, glabrescent. Culms and leaves glabrescent. Basal leaf sheaths smooth, shiny. Ligule coriaceous, truncate, $1 \mathrm{~mm}$ long. Auricles deltoid, acute to rounded, dark, 1-2 mm long, ciliate when young. Leaf blades pseudopetiolate, flat, 7-13 mm wide, the margins serrulate. Inflorescences $15-33 \mathrm{~cm}$ long, lax, densely covered in white indumentum, the branches loose and pendent, with secondary branching, the internodes and pedicels somewhat shorter or longer than the spikelets, the spikelets usually not overlapping. Sessile spikelets 3.5-4.5(-6.0) mm long, ovate, hermaphrodite, villous. Callus hairs 1-2 $\mathrm{mm}$ long. Lower glume with two keels, five- to seven-nerved, with cross-veins visible on the inner surface. Upper glume five- to seven-nerved. Anthers $2.5 \mathrm{~mm}$ long. Awns absent. Pedicellate spikelets the same as sessile spikelets, hermaphrodite or smaller and male. Sometimes the pedicel and the pedicellate spikelet reduced or absent on some branches. (Figs. 1B, 5).

Distribution: northern and central parts of the Malagasy highlands, with a single record from the northern wet forests (Fig. 8).

Habitat: shaded understory of wet forest, gallery forest and sometimes seasonal forest or tapia, often by the sides of streams; on laterite or granite; 700-1600m (the northernmost outlier record Humbert \& Capuron 21951 is recorded from 400-600m which could represent an error).

Notes: Easy to recognize by its silky snow-white inflorescences with pendent branches (Fig. 1B) and no awns. It is the only species of the genus fully lacking awns, a feature that could be related to its 
Malagasy Lasiorhachis

forest understory habitat. Of the two original annotated sheets from Hackel's herbarium, the chosen lectotype W1916-0028387 has the best flowering material. $2 n=20$ (Tateoka 3514).

Specimens examined: Madagascar. Antananarivo: Ambatolaona, 4 September 1956, Descoings, $B$. 1773 (TAN); Ambatolaona, Morat, P. 552 (TAN); Ambatolaona, 11 November 1912, Viguier, R. \& Humbert, H. 1196 (P); Ambohitantely, Peltier, J. \& Peltier, M. 4349 b (TAN); Analabe, Betsitra, October 1905, D'Alleizette, C. 1280 (P); Angavokely, May 1956, Bosser, J.M. 9579 (TAN); Angavokely, April 1959, Bosser, J.M. 12727 (TAN); Angavokely, October 1960, Bosser, J.M. 14648 (P, TAN); Angavokely, December 1960, Bosser, J.M. 14983 (P); Angavokely, 27 April 1947, Humbert, H. 20880 (P); Angavokely, 28 October 1970, Keraudren-Aymonin, M. \& Aymonin, G.G. 25229 (P); Angavokely, 28 October 1970, Keraudren-Aymonin, M. \& Aymonin, G.G. 25201 (P); Angavokely, 14 January 1960, Leandri, J. 2552 (P); Angavokely, October 1960, Leandri, J. 3219 (P); Angavokely, 10 January 1919, Perrier de la Bâthie, H. 12926 (P,P,TAN); Angavokely, 25 June 1964, Tateoka, T. 3514 (P, TAN); Antananarivo, 1960, Keraudren-Aymonin, M. 18 (P); Manankazo, September 1913, Perrier de la Bâthie, H. 10726 (P). Antsiranana: Lokoho, 1948, Humbert, H. \& Capuron, R. 21951(P). Fianarantsoa: Andohantanimenaha, Itremo, 25 February 2013, Vorontsova, M.S. et al. 1004 (K,TAN); Antsirakambiaty, Itremo, 12 March 2012, Vorontsova, M.S. et al. 739 (K,TAN); Itremo, Andohatanimena, 19 February 2014, Nanjarisoa, O.P. et al. 146 (K,TAN). Toamasina: Andasibe, 9 January 1911, Perrier de la Bâthie, H. 10830 (P); Andrangovalo, October 1937, Humbert, H. \& Cours, G. 17946 (P); Ankaraoka, October 1937, Humbert, H. \& Cours, G. 17534 (P); Lac Alaotra, Herbier de la Station Agricole de l' Alaotra 34 (TAN); Lac Alaotra, Herbier du Jardin Botanique de Madagascar 3415 (P); Moramanga, Anosibe, September 1953, Bosser, J.M. 6600 (P); Moramanga, August 1953, Bosser, J.M. 6618 (P); Nonokambo, 21 August 1937, Jardin Botanique de Tananarive 2851 (P); Sahamalaza, Manakambahiny Est, Dequaire, J. 27854 (P); Sahatandra, 16 October 1912, Viguier, R. \& Humbert, H. 764 (P); Sandrangato, December 1954, Descoings, B. 218 (P, TAN); Ambatovy, 24 November 2011, Bernard, R. et al. 1836 (P). 
Malagasy Lasiorhachis

2. Lasiorhachis perrieri (A.Camus) Bosser in Adansonia sér. 2, 8: 515.1968 EErianthus perrieri

A.Camus in Bull. Soc. Bot. France 71: 1182. 1925 =Miscanthidium perrieri (A.Camus) A.Camus in Bull. Soc. Bot. France 106: 339. 1959 =Saccharum perrieri (A.Camus) Clayton in Kew Bull. 35(4): 818. 1981. Type: MADAGASCAR, Antananarivo, Betafo, Oct 1913, H.Perrier de la Bâthie 10723 (Lectotype designated here: P [P00450374]!, isolectotype: P [P03370850]!).

Tufted perennial 1.5-2.0 m. Flowering culm 5-10 mm diameter at base. Nodes dark, glabrescent. Culms and leaves glabrescent. Basal leaf sheaths smooth, hardened. Ligule coriaceous, truncate, reddish, 2-4 mm long. Auricles absent or rounded, dark, up to $1 \mathrm{~mm}$ long, glabrous. Leaf blades flat, 10-15 mm wide, the margins serrulate. Inflorescences $20-30 \mathrm{~cm}$ long, dense, with brownish indumentum, the branches close together and largely erect, with secondary branching, the internodes and pedicels somewhat shorter than the spikelets, the spikelets overlapping. Sessile spikelets 3.0-4.0(-4.5) mm long, ovate, hermaphrodite, loosely hirsute to glabrous. Callus hairs 1-2 $\mathrm{mm}$ long. Lower glume with two keels, seven- to nine-nerved, with cross-veins visible on the inner surface. Upper glume three- to five-nerved. Anthers $2.8 \mathrm{~mm}$ long. Awns present, geniculate, twisted, 7-12 mm long, glabrous. Pedicellate spikelets similar to sessile spikelets but smaller, usually male with no awns, sometimes hermaphrodite with awns. (Figs. 1C-E, 6).

Distribution: restricted area of the Central Highlands in the Antananarivo and Fianarantsoa provinces. Known from five localities only. (Fig. 8).

Habitat: open rocky habitats near streams, on basalt or gneiss, 1300-1900 m (Fig. 1C).

Notes: The rarest member of the genus. Poor documentation of this species could be related to infrequent flowering, and the difficulty of identification in the vegetative state. A population of $L$. perrieri was recorded from Antsirakambiaty, Itremo, for the first time in 2014 (Fig. 1C-E) despite the fact that this commonly visited area has been the subject of numerous previous botanical surveys, including by the first author. Cultivation of this species has so far been unsuccessful. It is likely this 
Malagasy Lasiorhachis

species requires a reliable water supply; the population in Antsirakambiaty is found on the edge of a permanent stream. The lectotype sheet chosen here was previously marked as a holotype before the second duplicate was found; it is more extensively annotated and contains superior quality material.

Specimens examined: Madagascar. Antananarivo: Betafo, laves de l'lantsifitra, 25 December 1928, Humbert, H. 7138 (P); Tritriva, May 1912, Perrier de la Bâthie, H. 10849 (P). Fianarantsoa: Ambatofinandrahana, January 1953, Bosser, J.M. 5082 (TAN); Ambatofinandrahana, 25 January 1975, Croat, T.B. 29502 (TAN); Ambositra, January 1964, Bosser, J.M. 18996 (P, TAN, WAG); Antsirakambiaty, Itremo, 18 February 2014, Nanjarisoa, O.P. et al. 140 (K,TAN); Antsirakambiaty, Itremo, 19 May 2014, Vorontsova, M.S. \& Nanjarisoa, O.P. 1530 (TAN).

3. Lasiorhachis viguieri (A.Camus) Bosser in Adansonia sér. 2, 8: 515.1968 EErianthus viguieri A.Camus in Bull. Soc. Bot. France 71: 1182. 1925 =Miscanthidium viguieri (A.Camus) A.Camus in Bull. Soc. Bot. France 106: 339. 1959 इSaccharum viguieri (A.Camus) Clayton in Kew Bull. 35(4): 818. 1981. Type: MADAGASCAR, Antananarivo, Ambatolampy, pentes herbeuses sur le flanc ouest de I'Ankaratra, entre Ambatofotsy et le Tsiafajavona, 27 Nov 1912, R.Viguier \& H.M.Humbert 1721 (Holotype: P [P00450376]!, isotypes: P [P00450375, P00450377, P02356437]!).

= Miscanthidium antsirabense A.Camus in Bull. Soc. Bot. France 106: 338. 1959. Type:

MADAGASCAR, Antananarivo, environs d'Antsirabe, Jan 1914, H.Perrier de la Bâthie10753 (Holotype: P [P00450370]!, isotypes: P [P00450371, P00450372]).

Tufted perennial 0.50-1.15(-1.45) m. Flowering culm 1.5-4.0 mm diameter at base. Nodes villous. Culms and leaves glabrescent. Basal leaf sheaths smooth, shiny, sometimes breaking down into fibres. Ligule membranous, truncate, 1-4 mm long, surrounded by auricular hairs. Auricles absent. Leaf blades usually rolled, 3-11 mm wide, the margins smooth. Inflorescences 8-16 cm long, lax, with indumentum which is purple when fresh, the branches largely erect, usually branched only once, 
Malagasy Lasiorhachis

with limited secondary branching, the internodes and pedicels $1 / 2-3 / 4$ as long as the spikelets, the spikelets overlapping. Sessile spikelets (5-)6-9 mm long, ovate, hermaphrodite, villous to almost glabrous. Callus hairs 1-3 mm long. Lower glume with two keels, seven- to nine-nerved, with crossveins visible on the inner surface. Upper glume three- to five-nerved. Anthers 2.8-3.6 mm long. Awns present, geniculate, twisted, 8-20 mm long, glabrous. Pedicelled spikelets the same as sessile spikelets, hermaphrodite; sometimes reduced in size, male, with no awns. (Figs 1A, 7).

Distribution: central to southern highlands. (Fig. 8).

Habitat: open canopy montane grassy ecosystems, often associated with rocky outcrops and streams, often with Erica L.; (1500-)1700-2500 m (Fig. 1A).

Notes: This is the most common and abundant Lasiorhachis sp., dominating a range of higher elevation flammable $\mathrm{C}_{4}$ habitats, including the rocky plateau grassland at Andringitra National Park (plot 6; Vorontsova et al., 2016). Found in drier and more open habitats than L. hildebrandtii and L. perrieri, frequently those prone to fire. Charred leaf sheaths are frequently seen on herbarium specimens. Adaptations to drier habitat could include its smaller height, and leaf blades that are usually rolled; specimens with flat leaves could represent individuals growing in more humid environments. The holotype sheet of Erianthus viguieri is the only one directly annotated by Aimée Camus. The holotype sheet of Miscanthidium antsirabense shows signs of several annotates by Aimée Camus, including pencil marks linking it to Miscanthidium viguieri.

Specimens examined: Madagascar. Antananarivo: Ambatolampy, Ankaratra, February 1957, Bosser, J.M. 10748 (G, K, MO, P); Anjozorobe, December 1958, Bosser, J.M. 12401a (TAN); Ankaratra, November 1955, Bosser, J.M. 8665 (P,TAN); Antananarivo, May 1962, Bosser, J.M. 16304 (P); Antananarivo, Gillard s.n. (P); Antanifotsy, Ambohimandroso, December 1955, Bosser, J.M. 8900 (P, TAN); Antsampandrano, Ankaratra, December 1963, Bosser, J.M. 18490 (P, TAN); Antsirabe, May 1913, Perrier de la Bâthie, H. 15797 (P); Behenjy, May 1962, Bosser, J.M. 15427 (P, TAN); Carion, 
Malagasy Lasiorhachis

December 1958, Bosser, J.M. 12401 b (P); Carion, October 1959, Bosser, J.M. $13256 b$ (P); Faratsiho, entre Ambatondradama et Ambatofotsy, 26 December 1912, Viguier, R. \& Humbert, H. 1624 (P); laranandriana, January 1954, Bosser, J.M. 7198 (P); Iaranandriana, January 1954, Bosser, J.M. 7202 (P,TAN); Manjakatompo, 19 December 1950, Benoist, R. 475 (P); PK 28 route du sud, April 1962, Bosser, J.M. 15572 (P); PK 39 route du sud, May 1962, Bosser, J.M. 15474 (P); Tsiafajavona, February 1957, Bosser, J.M. 10760 (P); Ibity, June 1967, Morat, P. 2864 (P, TAN). Fianarantsoa: Andringitra, 1924, Humbert, H. 3647 (P); Andringitra, 28 November 2013, Nanjarisoa, O.P. et al. 77 (K, P, TAN); Andringitra, 13 December 2013, Vorontsova, M.S. et al. 1245 (TAN); Andringitra, 13 December 2013, Vorontsova, M.S. et al. 1248 (TAN); Andringitra, 13 December 2013, Vorontsova, M.S. et al. 1259 (TAN); Andringtra, Andohariana, 13 January 1971, Guillaumet, J.L. 3745 (P); Andringtra, 28 November 2013, Nanjarisoa, O.P. et al. 76 (K,TAN); Fandriana, Miarinavaratra, January 1953, Bosser, J.M. 5071 (P); Manandriana, Ivato, January 1964, Bosser, J.M. 18791 (P); Pic Boby, Andringitra, April 1964, Bosser, J.M. 19441 (P, TAN); Andringitra, 25 November 2009, Couch, C. et al. 589 (K, P);

\section{ACKNOWLEDGEMENTS}

We would like to thank the staff of the Kew Madagascar Conservation Centre, Stuart Cable (RBG Kew), and Parc de Tsimbazaza for their long-term collaboration and support for Madagascar Poaceae research. The Direction Générale des Forêts and Madagascar National Parks generously granted our research permits. JH acknowledges an Idex UNITI mobility grant (RECAC15EX110; University of Toulouse) for fieldwork in Madagascar. GB is a member of the Laboratoire Evolution \& Diversité Biologique (EDB) part of the LABEX “TULIP" managed by Agence Nationale de la Recherche (ANR-10LABX-0041) and LABEX “CEBA" (ANR-10-LABX-25-01). Curators of the Muséum National d'Histoire Naturelle herbarium (P) and Parc de Tsimbazaza herbarium (TAN) made specimens available. Lucy Smith made the beautiful drawings, and Sarah Ficinski created the distribution map. We are grateful to Cassiano Welker (Universidade Federal de Uberlândia), Michael R. McKain (University of Alabama) and Elizabeth Kellogg (Donald Danforth Plant Science Center) for discussion on Andropogoneae 
Malagasy Lasiorhachis

evolution and the genus Eulalia. Thanks also to Emmet Judziewicz and an anonymous reviewer whose comments improved this manuscript.

REFERENCES

Aitken K, Berkman P, Rae A. 2016. The first sugarcane genome assembly: how can we use it? Proceedings of the Australian Society Sugar Cane Technology 38.

https://www.assct.com.au/media//pdfs/members/Ag\%2005\%20Aitken\%20et\%20al.pdf. Accessed 19 December 2017.

Altekar G, Dwarkadas S, Huelsenbeck JP, Ronquist F. 2004. Parallel Metropolis coupled Markov chain Monte Carlo for Bayesian phylogenetic inference. Bioinformatics 20: 407-415.

Arthan W, McKain MR, Traiperm P, Welker CAD, Teisher JK, Kellogg EA. 2017. Phylogenomics of Andropogoneae (Panicoideae: Poaceae) of mainland Southeast Asia. Systematic Botany 42: 418431.

Besnard G, Christin P-A, Malé P-JG, Coissac E, Ralimanana H, Vorontsova MS. 2013. Phylogenomics and taxonomy of Lecomtelleae (Poaceae), an isolated panicoid lineage from Madagascar. Annals of Botany 112: 1057-1066.

Bosser J. 1968. Note sur les graminées de Madagascar-VII. Adansonia 8: 513-522.

Bosser J. 1969. Graminées des pâturages et des cultures à Madagascar. Paris, France: ORSTOM.

Brosse N, Dufour A, Meng X, Sun Q, Ragauskas A. 2012. Miscanthus: a fast-growing crop for biofuels and chemicals production. Biofuels, Bioproducts and Biorefining 6: 580-598.

Brozynska M, Furtado A, Henry RJ. 2016. Genomics of crop wild relatives: expanding the gene pool for crop improvement. Plant Biotechnology Journal 14: 1070-1085. 
Malagasy Lasiorhachis

Burke SV, Wysocki WP, Zuloaga FO, Craine JM, Pires JC, Edger PP, Mayfield-Jones D, Clark LG,

Kelchner SA, Duvall MR. 2016. Evolutionary relationships in panicoid grasses based on plastome phylogenomics (Panicoideae; Poaceae). BMC Plant Biology 16: 140.

Castañeda-Álvarez NP, Khoury CK, Achicanoy HA, Bernau V, Dempewolf H, Eastwood RJ, Guarino L, Harker RH, Jarvis A, Maxted N, Müller JV, Ramirez-Villegas J, Sosa CC, Struik PC, Vincent H, Toll J. 2016. Global conservation priorities for crop wild relatives. Nature Plants 2: 16022.

Camacho C, Coulouris G, Avagyan V, Ma N, Papadopoulos J, Bealer K, Madden TL. 2009. BLAST+: architecture and applications. BMC Bioinformatics 10: 421.

Camus A. 1924. Espèces nouvelles d'Erianthus malgaches. Bulletin de la Société Botanique de France 71: $1182-1183$.

Camus A. 1959. Section, espèces et sous-espèces nouvelles de graminées malgaches. Bulletin de la Société Botanique de France 106: 337-340.

Clayton WD. 1981. Notes on the tribe Andropogoneae (Gramineae). Kew Bulletin 35: 813-818.

Clayton WD, Renvoize SA. 1986. Genera graminum. Grasses of the World. Kew: Royal Botanic Gardens.

Daniels C., Daniels J. 1975. The geographical, historical, and cultural aspects of the origin of Indian and Chinese sugarcanes, S. barberi and S. sinense. International Journal of Sugar Cane Breeders' Newsletter 36: 4-23.

Dempewolf H, Baute G, Anderson J, Kilian B, Smith C, Guarino L. 2017. Past and future use of wild relatives in crop breeding. Crop Science 57: 1070-1082.

Energy Biosciences Institute and Joint Genome Institute. 2017. Miscanthus sinensis v7.1 Available on Phytozome, https://phytozome.jgi.doe.gov/pz/portal.html\#!info?alias=Org Msinensis er, accessed on 6 March 2019. 
Malagasy Lasiorhachis

Estep MC, McKain MR, Diaz DV, Zhong J, Hodge JG, Hodkinson TR, Layton DJ, Malcomber ST,

Pasquet R, Kellogg EA. 2014. Allopolyploidy, diversification, and the Miocene grassland expansion. Proceedings of the National Academy of Sciences of the United States of America 111: $15149-15154$

Evans DL, Joshi SV, Wang J. 2019. Whole chloroplast genome and gene locus phylogenies reveal the taxonomic placement and relationship of Tripidium (Panicoideae: Andropogoneae) to sugarcane. BMC Evolutionary Biology 19: 33.

FAOSTAT. 2019. Food and agriculture data. Food and Agriculture Organization of the United Nations, http://www.fao.org/faostat/en/, accessed on 18 January 2019.

Garsmeur O, Droc G, Antonise R, Grimwood J, Potier B, Aitken K, Jenkins J, Martin G, Charron C, Hervouet C, Costet L, Yahiaoui N, Healey A, Sims D, Cherukuri Y, Sreedasyam A, Kilian A, Chan A, Sluys MAV, Swaminathan K, Town C, Bergès H, Simmons B, Glaszmann JC, Vossen E van der, Henry R, Schmutz J, D’Hont A. 2018. A mosaic monoploid reference sequence for the highly complex genome of sugarcane. Nature Communications 9: 2638.

Hackel E. 1885. Andropogoneae novae. Flora 68: 131-143.

Hackel E. 1889. Andropogon subgenus Lasiorhachis. Monographiae Phanerogamarum 6: 471-473.

Hackel J, Vorontsova MS, Nanjarisoa OP, Hall RC, Razanatsoa J, Malakasi P, Besnard G. 2018. Grass diversification in Madagascar: In situ radiation of two large $C_{3}$ shade clades and support for a Miocene to Pliocene origin of $\mathrm{C}_{4}$ grassy biomes. Journal of Biogeography 45: 750-761.

Hawkins JS, Ramachandran D, Henderson A, Freeman J, Carlise M, Harris A, Willison-Headley Z. 2015. Phylogenetic reconstruction using four low-copy nuclear loci strongly supports a polyphyletic origin of the genus Sorghum. Annals of Botany 116: 291-299. 
Malagasy Lasiorhachis

Heaton EA, Dohleman FG, Long SP. 2008. Meeting US biofuel goals with less land: the potential of Miscanthus. Global Change Biology 14: 2000-2014.

Hodkinson TR, Chase MW, Lledó DM, Salamin N, Renvoize SA. 2002. Phylogenetics of Miscanthus, Saccharum and related genera (Saccharinae, Andropogoneae, Poaceae) based on DNA sequences from ITS nuclear ribosomal DNA and plastid trnL intron and $\operatorname{trnL}-F$ intergenic spacers. Journal of Plant Research 115: 381-392.

Katoh K, Standley DM. 2013. MAFFT Multiple Sequence Alignment Software Version 7: improvements in performance and usability. Molecular Biology and Evolution 30: 772-780.

Kellogg EA. 2013. Phylogenetic Relationships of Saccharinae and Sorghinae. In: Paterson AH (ed.) Genomics of the Saccharinae. Plant genetics and genomics: crops and models, vol. 11. New York: Springer, 3-21.

Kellogg EA. 2015. Flowering plants. Monocots: Poaceae. In: Kubitzki K (ed.), The families and genera of vascular plants, vol. 13. Heidelberg: Springer.

Moat J, Smith P. 2007. Atlas of the vegetation of Madagascar. Kew: Royal Botanic Gardens.

Mukherjee SK. 1954. Revision of the genus Saccharum Linn. Bulletin of the Botanical Society of Bengal 8: 143-148.

Paterson AH, Bowers JE, Bruggmann R, Dubchak I, Grimwood J, Gundlach H, Haberer G, Hellsten U, Mitros T, Poliakov A, Schmutz J, Spannagl M, Tang H, Wang X, Wicker T, Bharti AK, Chapman J, Feltus FA, Gowik U, Grigoriev IV, Lyons E, Maher CA, Martis M, Narechania A, Otillar RP, Penning BW, Salamov AA, Wang Y, Zhang L, Carpita NC, Freeling M, Gingle AR, Hash CT, Keller B, Klein P, Kresovich S, McCann MC, Ming R, Peterson DG, Mehboob-ur-Rahman, Ware D, Westhoff P, Mayer KFX, Messing J, Rokhsar DS. 2009. The Sorghum bicolor genome and the diversification of grasses. Nature 457: 551-556. 
Malagasy Lasiorhachis

Piot A, Hackel J, Christin PA, Besnard G. 2018. One-third of the plastid genes evolved under positive selection in PACMAD grasses. Planta 247: 255-266.

Ronquist F, Huelsenbeck JP. 2003. MrBayes 3: Bayesian phylogenetic inference under mixed models. Bioinformatics 19: 1572-1574.

Sacks EJ, Juvik JA, Lin Q, Stewart JR, Yamada T. 2013. The gene pool of Miscanthus species and its improvement. In: Paterson AH (ed.), Genomics of the Saccharinae. Plant genetics and genomics: crops and models, vol. 11. New York: Springer New York, 73-101.

Spangler RE. 2003. Taxonomy of Sarga, Sorghum and Vacoparis (Poaceae: Andropogoneae). Australian Systematic Botany 16: 279-299.

Solofondranohatra CL, Vorontsova MS, Hackel J, Besnard G, Cable S, Williams J, Jeannoda V, Lehmann CER. 2018. Grass functional traits differentiate forest and savanna in the Madagascar central highlands. Frontiers in Ecology and Evolution 6: 184.

Soreng RJ, Peterson PM, Romaschenko K, Davidse G, Teisher JK, Clark LG, Barberá P, Gillespie L, Zuloaga FO. 2017. A worldwide phylogenetic classification of the Poaceae (Gramineae) II: an update and a comparison of two 2015 classifications. Journal of Systematics and Evolution 55: 259-290.

Stapf O. 1933 publ. 1927. Lasiorrhachis hildebrandtii. Hooker's Icones Plantarum 32: t. 3124.

Todd J, Sandhu H, Hale A, Glaz B, Wang J. 2017. Phenotypic evaluation of a diversity panel selected from the world collection of sugarcane (Saccharum spp.) and related grasses. Maydica 62: 19.

\section{Vorontsova MS, Besnard G, Forest F, Malakasi P, Moat J, Clayton WD, Ficinski P, Savva GM,} Nanjarisoa OP, Razanatsoa J, Randriatsara FO, Kimeu JM, Luke WRQ, Kayombo C, Linder HP. 2016. Madagascar's grasses and grasslands: anthropogenic or natural? Proceedings of the Royal Society, Series B 283: 20152262. 
Malagasy Lasiorhachis

Vorontsova MS, Dransfield S, Renvoize S, Besnard G, McRobb A, Razanatsoa J, Nanjarisoa OP, Andrianaivoravelona B, Rakotoarisoa SE, Ralimanana H. 2018. Identification guide to grasses and bamboos in Madagascar. Kew: Royal Botanic Gardens.

Watson L, Macfarlane TD, Dallwitz MJ. 1992 onwards. The grass genera of the world: descriptions, illustrations, identification, and information retrieval; including synonyms, morphology, anatomy, physiology, phytochemistry, cytology, classification, pathogens, world and local distribution, and references. Version: 15th February 2019. delta-intkey.com

Welker CAD, McKain MR, Vorontsova MS, Peichoto MC, Kellogg EA. 2019. Plastome phylogenomics of sugarcane and relatives confirms the segregation of the genus Tripidium (PoaceaeAndropogoneae), Taxon 68: 246-267.

Welker CAD, Souza-Chies TT, Longhi-Wagner HM, Peichoto MC, McKain MR, Kellogg EA. 2015.

Phylogenetic analysis of Saccharum s.l. (Poaceae; Andropogoneae), with emphasis on the circumscription of the South American species. American Journal of Botany 102: 248-263.

Zhang H, Mittal N, Leamy L, Barazani O, Song BH. 2017. Back into the wild-apply untapped genetic diversity of wild relatives for crop improvement. Evolutionary Applications 10: 5-24.

Zhuang Q, Qin Z, Chen M. 2013. Biofuel, land and water: maize, switchgrass or Miscanthus? Environmental Research Letters 8: 015020. 
Malagasy Lasiorhachis

\section{FIGURE LEGENDS}

Figure 1. Field photographs of Lasiorhachis. A, Lasiorhachis viguieri in Andringitra National Park, Nanjarisoa et al. 77; B, Lasiorhachis hildebrandtii in Alaotra-Mangoro; C-E Lasiorhachis perrieri in Itremo Protected Area, Vorontsova et al. 1530. Photographs by M.S. Vorontsova except B by Romer Rabarijaona at www.inaturalist.org.

Figure 2. Bayesian phylogenetic tree estimated for non-coding regions of 56 Andropogoneae plastomes, including two Lasiorhachis spp. (in bold). Subtribe Saccharinae and the Saccharum complex are highlighted. Filled circles at nodes indicate a posterior clade support of 0.95 and higher with both non-coding plastome regions and coding regions; open circles indicate support only with coding regions. See Figure S1 for precise node support values and plastome accession numbers.

Figure 3. Bayesian phylogenetic tree estimated for the plastid regions $n d h F, r b c L$ and $t r n K / m a t K$ for Saccharinae species, including four Lasiorhachis accessions (in bold), and outgroup taxa. The Saccharum complex is highlighted. Circles at nodes indicate a posterior clade support of 0.7 and higher (open circles) or 0.95 and higher (filled circles).

Figure 4. Schematic representation of Bayesian phylogenetic trees estimated for Andropogoneae sequences of ITS (A) and eight low-copy nuclear regions (B-I). Lasiorhachis (arrow) and other clades of interest of Saccharinae are highlighted. Triangle size is not proportional to the number of collapsed tips. Sequences for two Lasiorhachis accessions were assembled from low-coverage genome skims. All trees were rooted with Arundinella. The scale bar indicates 0.05 substitutions per site, and circles at nodes indicate posterior support of 0.7 and higher (open) or 0.95 and higher (filled).

Figure 5. Lasiorhachis hildebrandtii. A, habit; B, junction between the leaf sheath and the left blade, lateral view; C, ligule; D, inflorescence branch; E, spikelet pair; F- M, sessile spikelet; F, lower glume, 
Malagasy Lasiorhachis

ventral surface; G, lower glume, dorsal surface; $H$, upper glume, ventral surface; I, upper glume, dorsal surface; J, lower lemma, ventral surface; K, lower lemma, dorsal surface; L, upper lemma, ventral surface; $M$, upper lemma, dorsal surface. Scale bar: $A=4 \mathrm{~cm}, B, C=4 \mathrm{~mm}, D=5 \mathrm{~mm}, E=2$ $\mathrm{mm}, \mathrm{F}-\mathrm{M}=1.6 \mathrm{~mm}$. Drawn from Descoings $218(\mathrm{~K})$ by Lucy T. Smith.

Figure 6. Lasiorhachis perrieri: A, habit at base; B, flowering habit, culm continued from A; C, ligule; $D$, inflorescence branch; E, spikelet pair; F-R, sessile spikelet; F, lower glume, ventral surface; $G$, lower glume, dorsal surface; $\mathrm{H}$, upper glume, ventral surface; I, upper glume, dorsal surface; J, spikelet with the glumes removed, lateral view; K, lower lemma, ventral surface; L, lower lemma, dorsal surface; $M$, lower palea, ventral surface; $N$, lower palea, dorsal surface; $\mathrm{O}$, upper lemma, ventral surface; $P$, upper lemma, dorsal surface; $Q$, lodicules; $R$, immature caryopsis. Scale bar: $A, B=$ $4 \mathrm{~cm}, \mathrm{C}, \mathrm{D}=5 \mathrm{~mm}, \mathrm{E}=2.2 \mathrm{~mm}, \mathrm{~F}-\mathrm{R}=2 \mathrm{~mm}$. Drawn from Bosser 1899b (K) by Lucy T. Smith.

Figure 7. Lasiorhachis viguieri. A, habit; B, ligule; C, inflorescence branch; D, spikelet pair; E-N, sessile spikelet; E, lower glume, ventral surface; F, lower glume, dorsal surface; G, upper glume, ventral surface; $\mathrm{H}$, upper glume, dorsal surface; I, spikelet with the glumes removed, lateral view; J, lower lemma, ventral surface; $K$, lower lemma, dorsal surface; L, upper lemma; $M$, lodicule; $N$, gynoecium; $\mathrm{O}-\mathrm{T}$, pedicelled spikelet; $\mathrm{O}$, lower glume, ventral surface; $\mathrm{P}$, lower glume, dorsal surface; $Q$, upper glume, ventral surface; $R$, upper glume, dorsal surface; $S$, lower lemma; $T$, upper lemma. Scale bar: $A=4 \mathrm{~cm}, B=1.6 \mathrm{~mm}, \mathrm{C}=7 \mathrm{~mm}, \mathrm{D}-\mathrm{T}=2.2 \mathrm{~mm}$. Drawn from Nanjarisoa 76 (K) by Lucy T. Smith.

Figure 8. Distribution of Lasiorhachis including occurrence records from the specimens studied here and field observations. Administrative province boundaries are marked in grey.

Appendix 1. Sequences assembled as part of this study. [to be added after review]

\author{
SUPPLEMENTARY MATERIAL
}




\section{Malagasy Lasiorhachis}

Figure S1. Detailed versions of Bayesian phylogenetic trees estimated for coding (A) and non-coding plastome regions, with Bayesian posterior support values at nodes and plastome accession numbers.

Figure S2. Detailed versions of Bayesian phylogenetic trees estimated for ITS (A) and eight low-copy nuclear regions (B-I), with Bayesian posterior support values at nodes and accession numbers. 

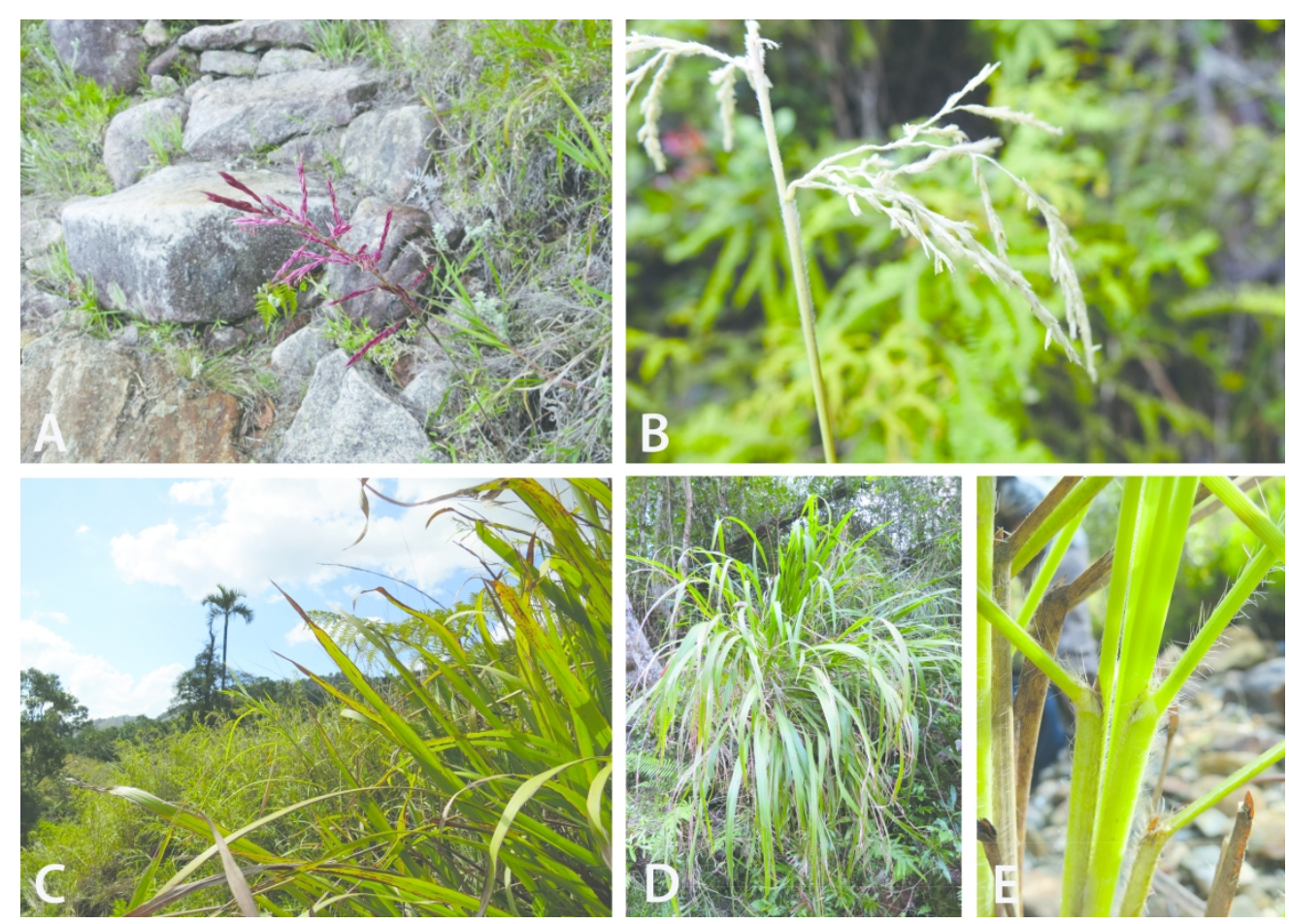

$287 \times 203 \mathrm{~mm}(300 \times 300$ DPI $)$ 


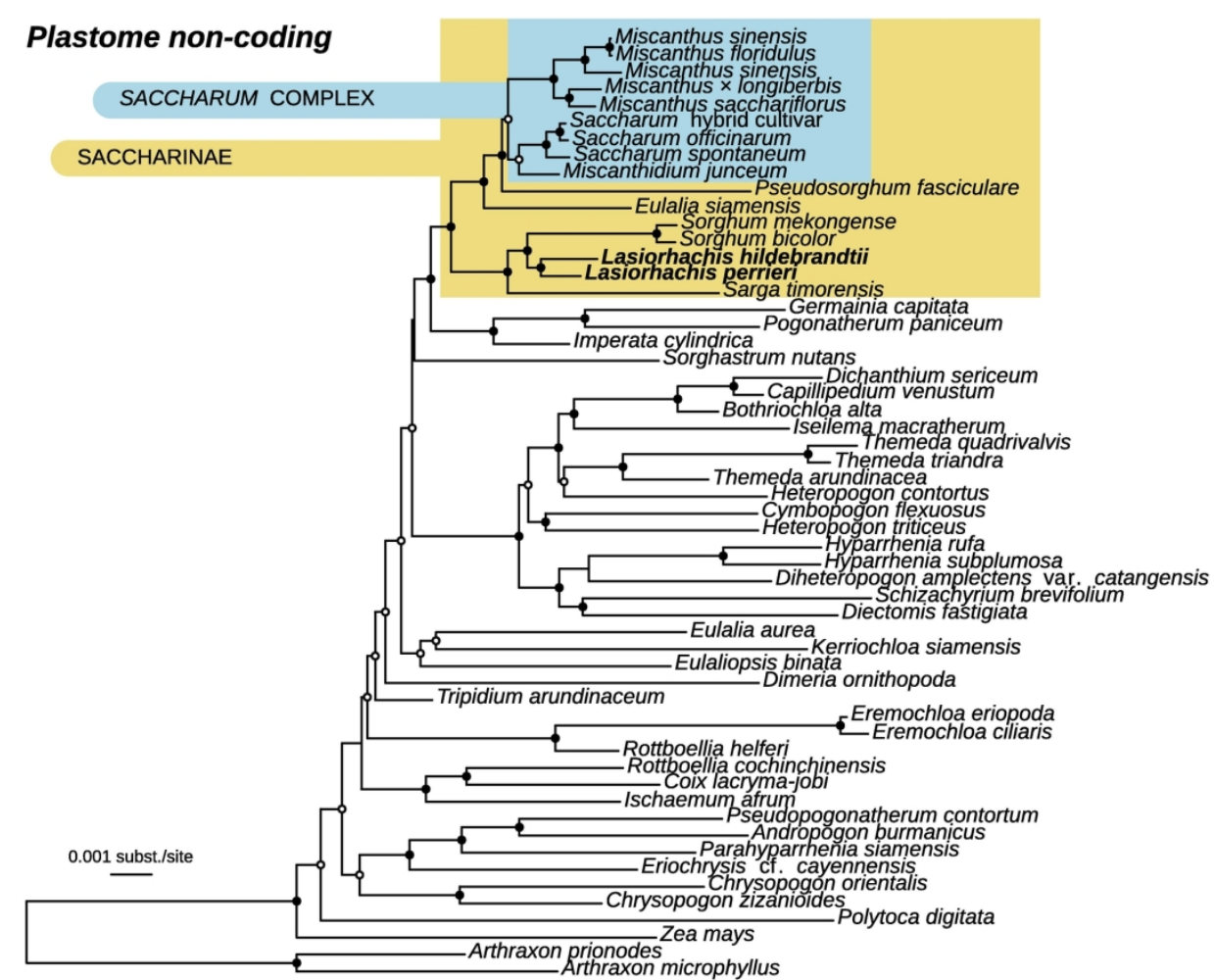

$167 \times 139 \mathrm{~mm}(300 \times 300 \mathrm{DPI})$ 


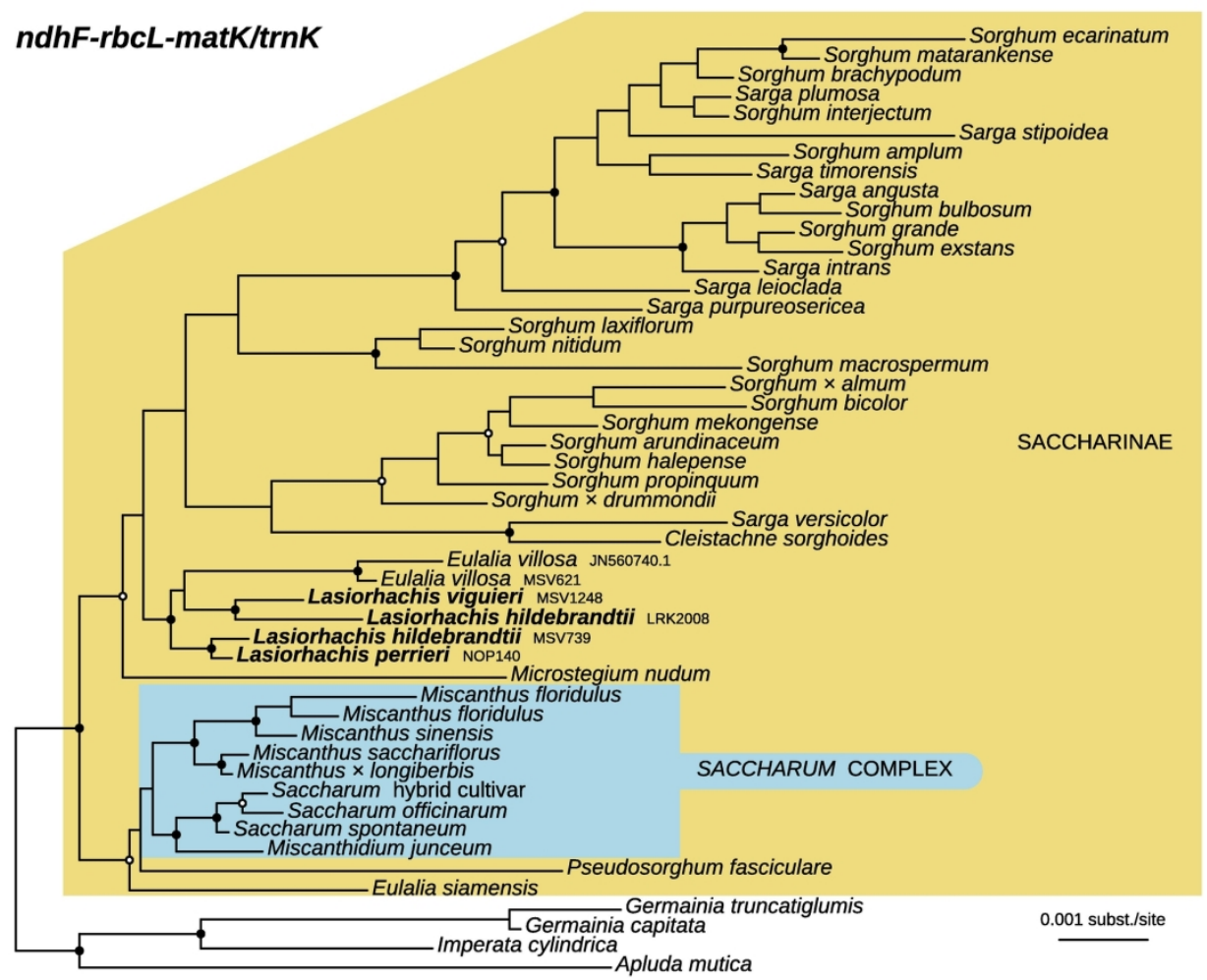

Figure 3.

$167 \times 139 \mathrm{~mm}(300 \times 300 \mathrm{DPI})$ 

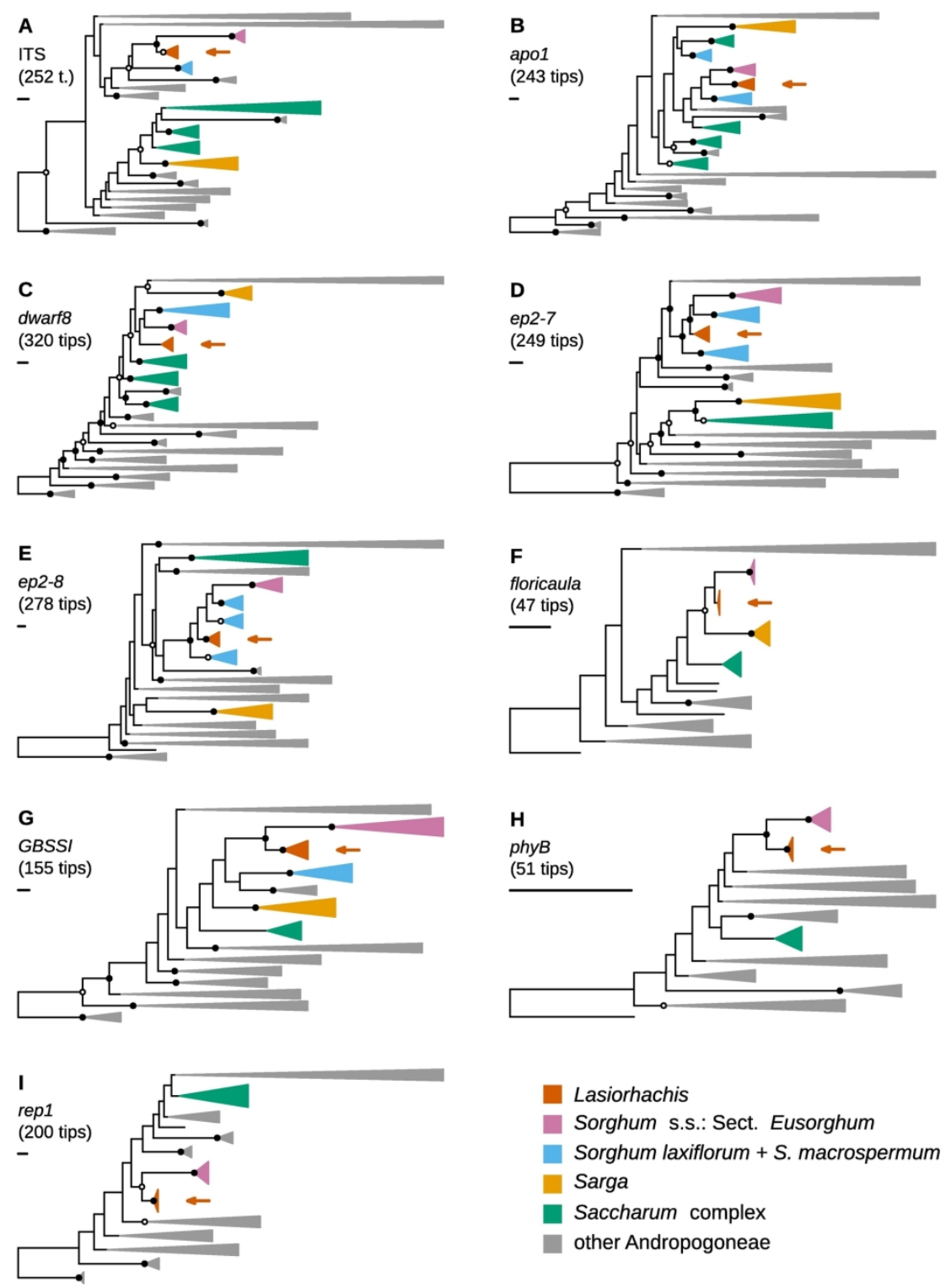

Lasiorhachis

Sorghum s.s.: Sect. Eusorghum

Sorghum laxiflorum + S. macrospermum

Sarga

Saccharum complex

other Andropogoneae

$167 \times 224 \mathrm{~mm}(300 \times 300 \mathrm{DPI})$ 


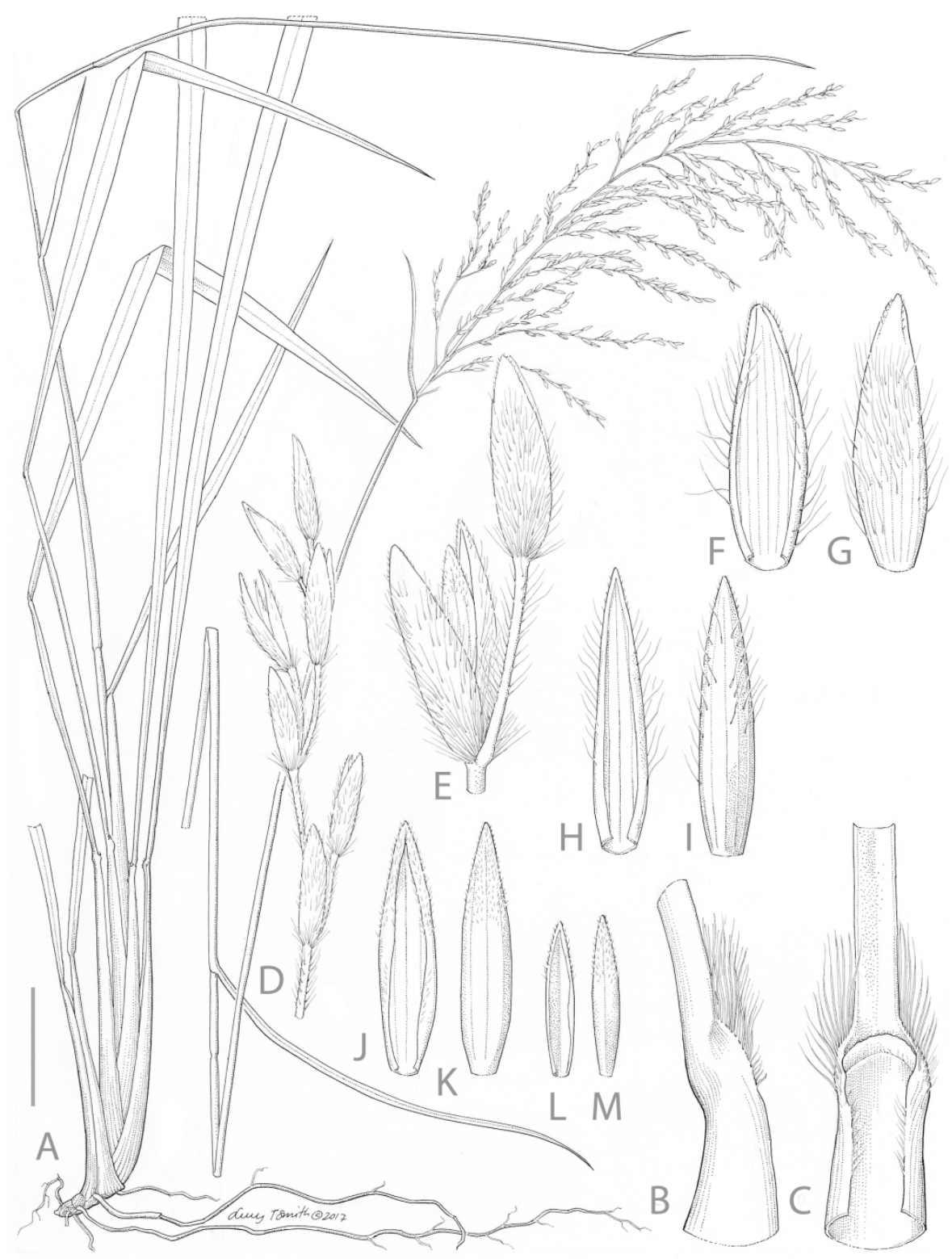

Botanical Journal of the Linnean Society 


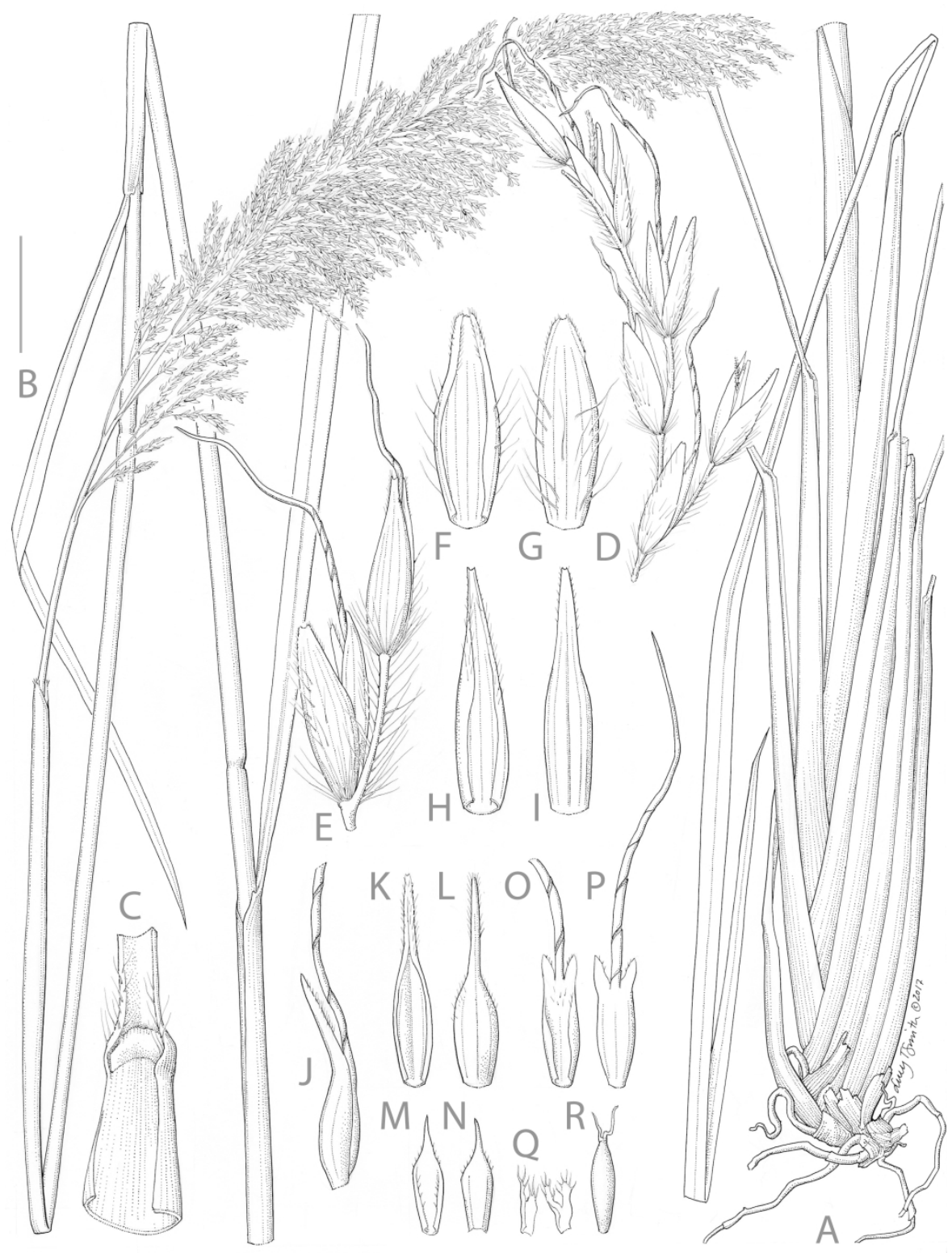

Botanical Journal of the Linnean Society 


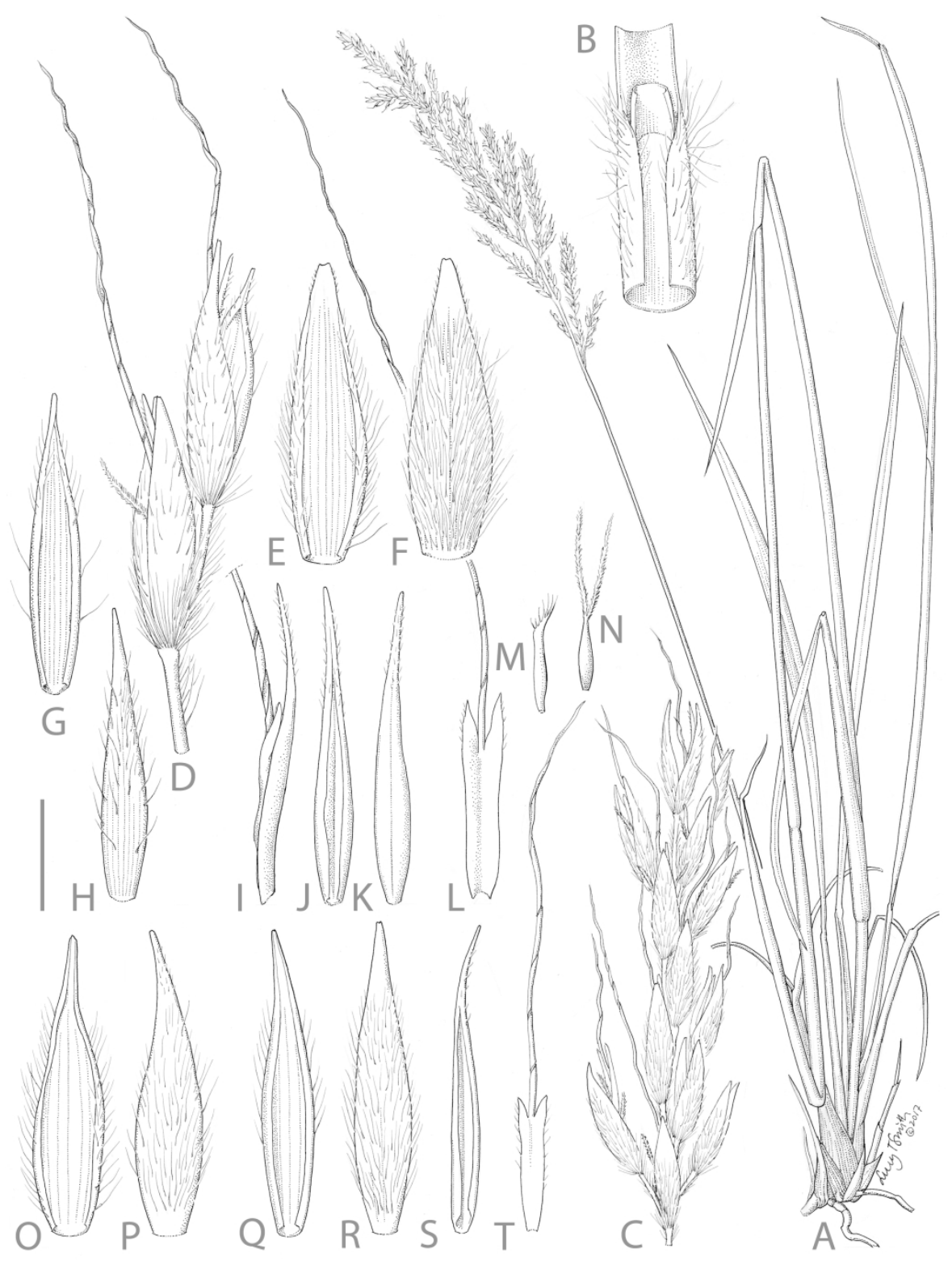

Botanical Journal of the Linnean Society 


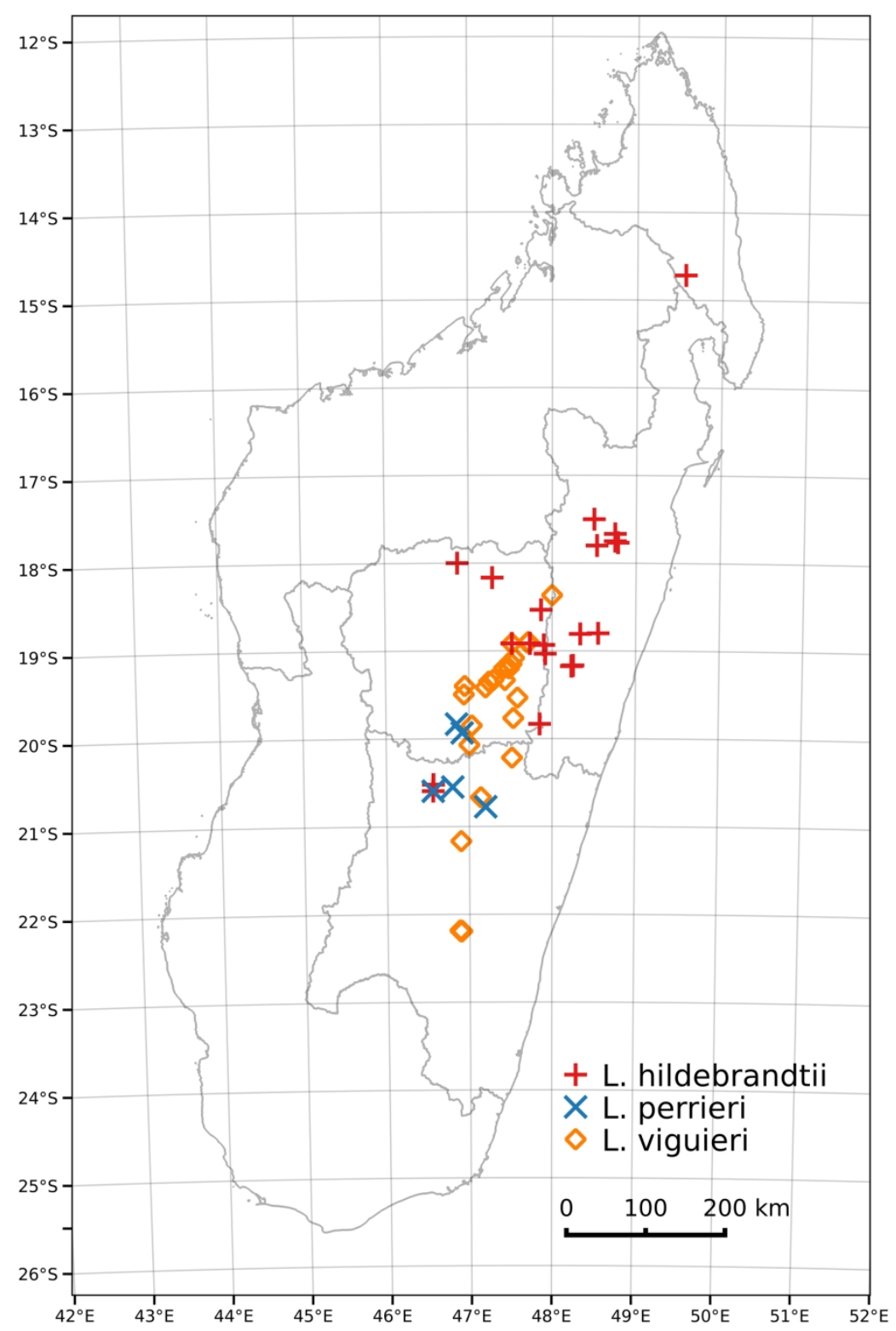

$84 \times 126 \mathrm{~mm}(600 \times 600 \mathrm{DPI})$ 


\section{A - Plastome CDS}

0.001 subst./site
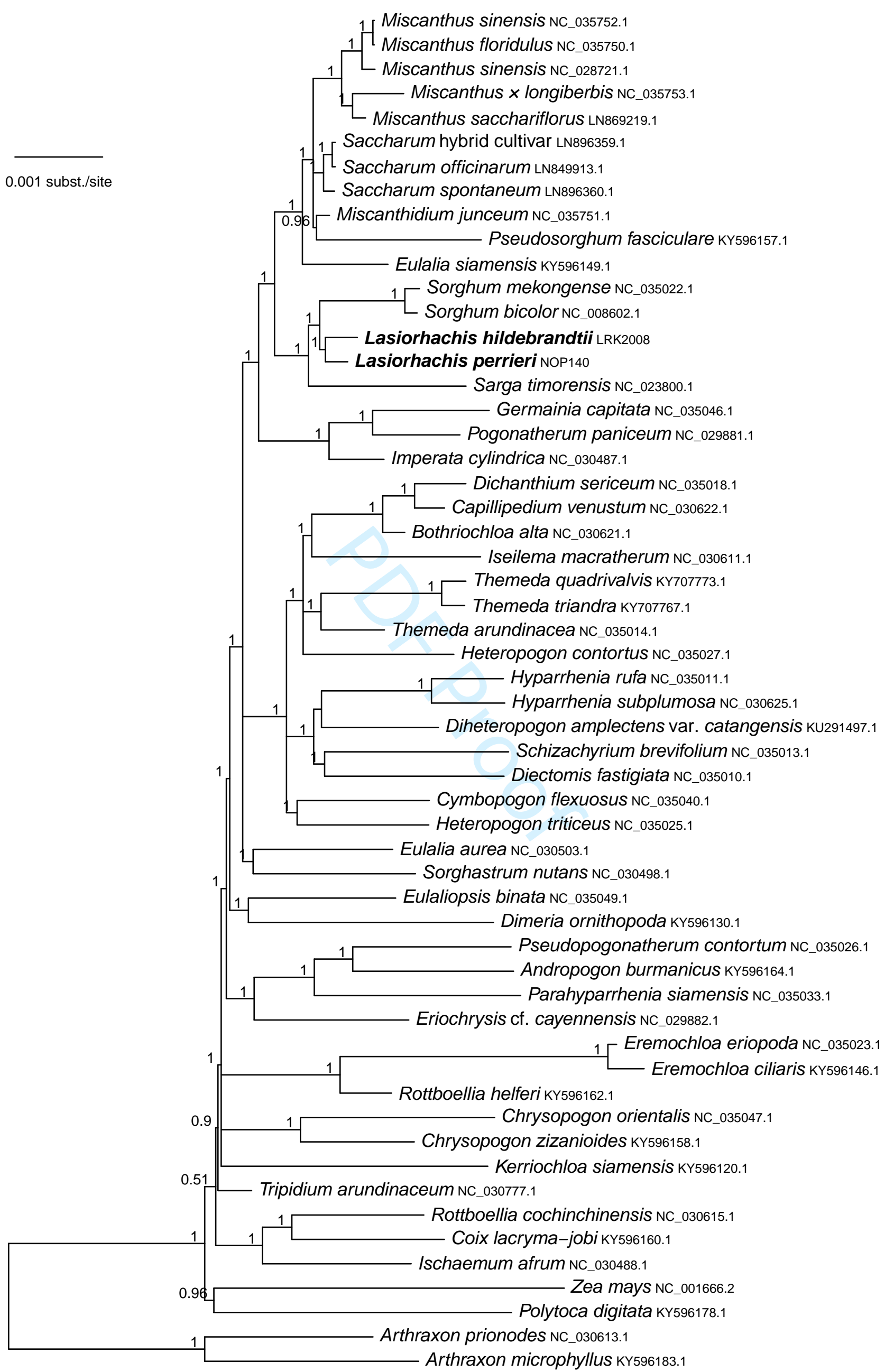


\section{B - Plastome non-coding}

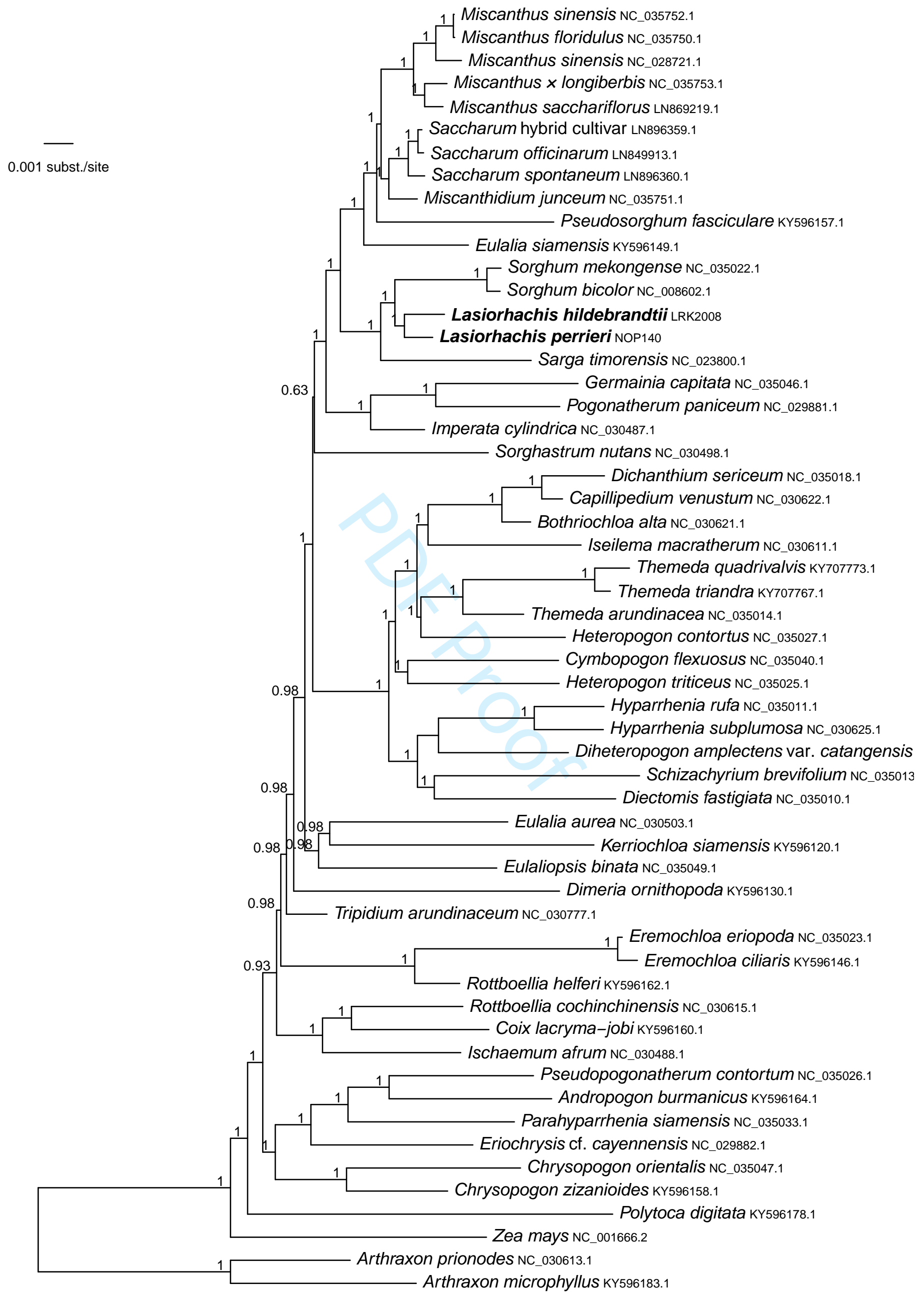




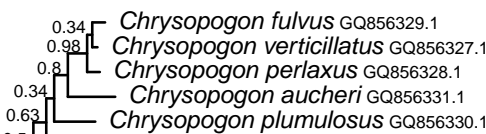

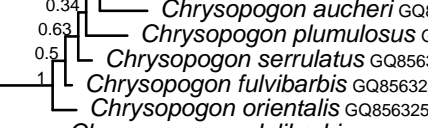

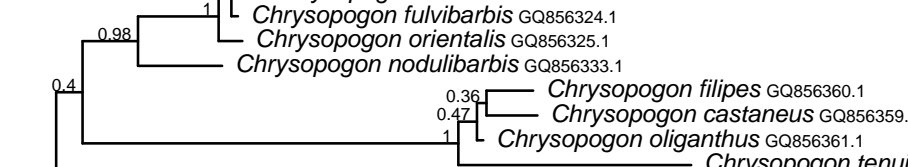

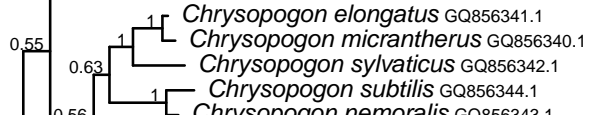

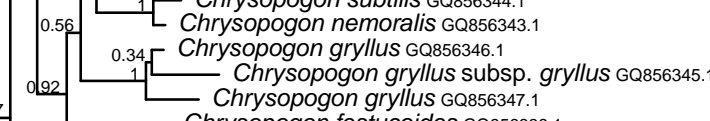

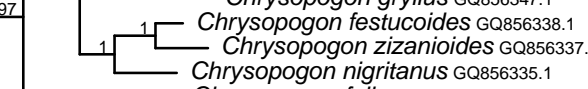

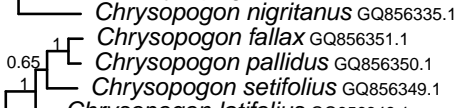

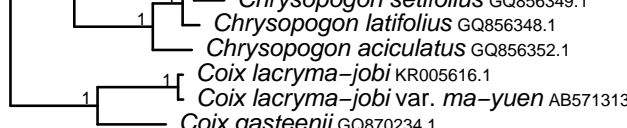

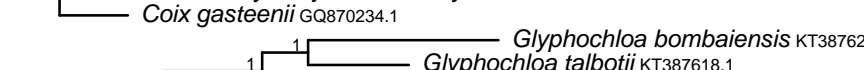

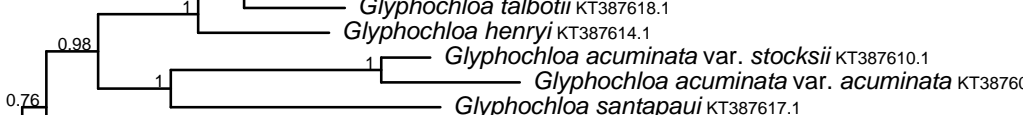

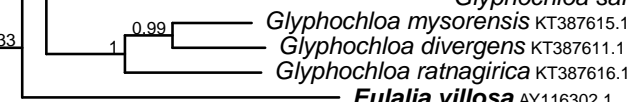

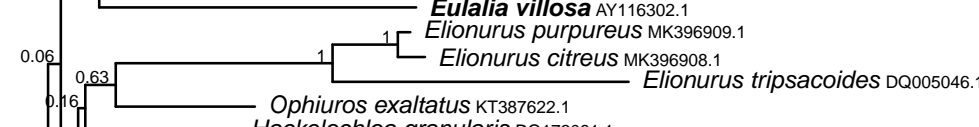

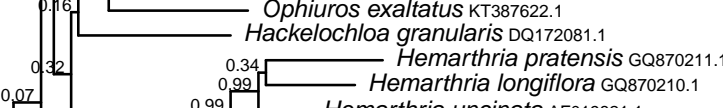

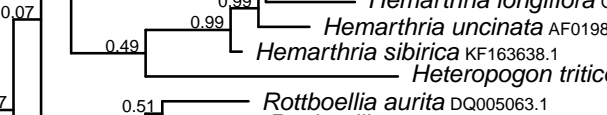

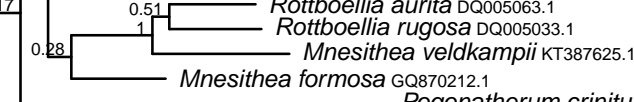

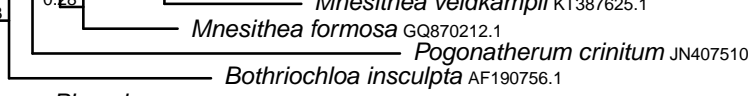

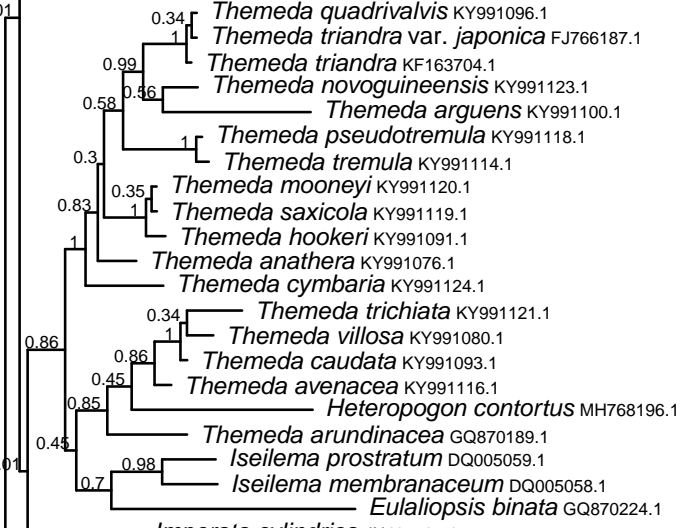

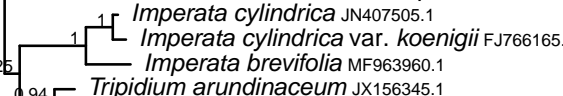

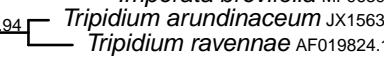

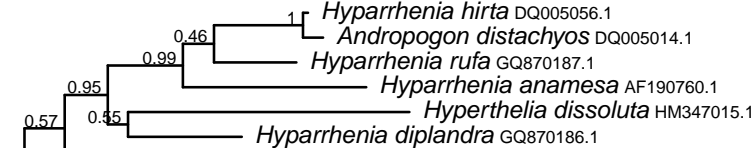

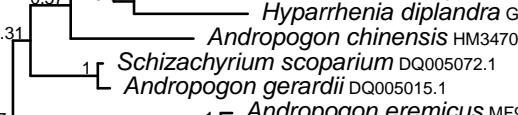

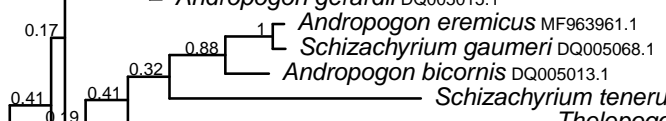

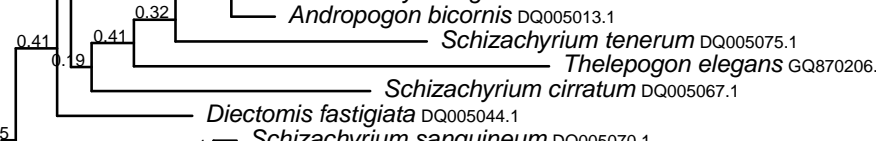

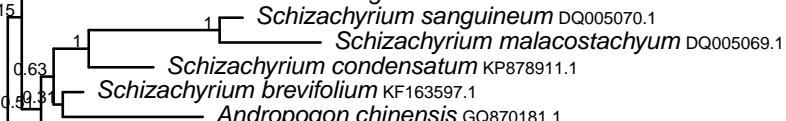

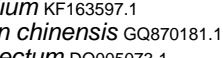

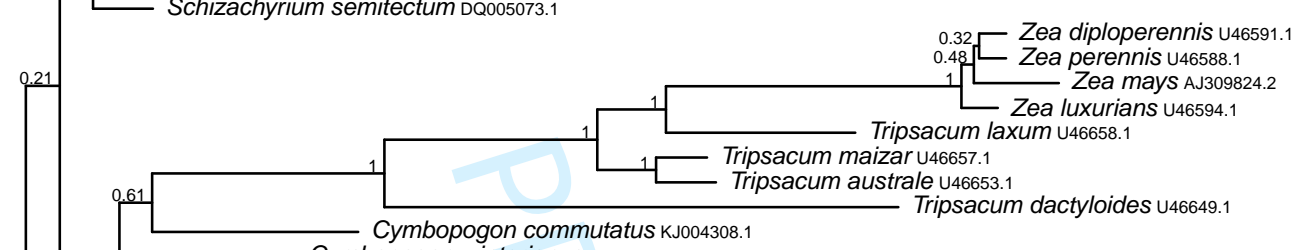

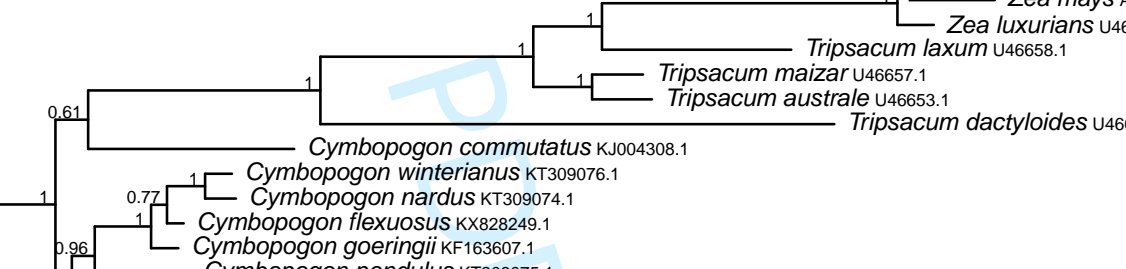

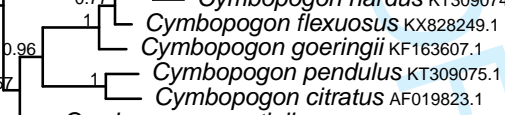

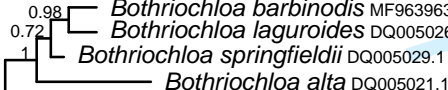

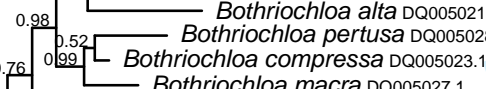

1.

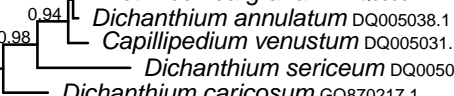

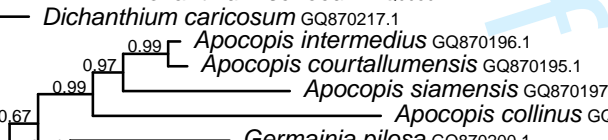

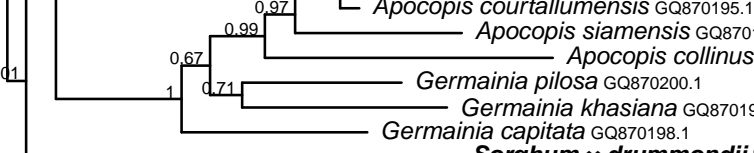

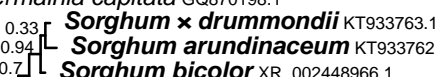

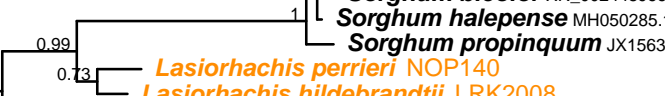

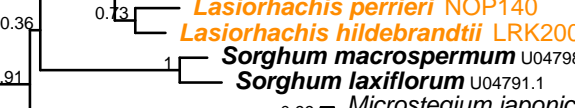

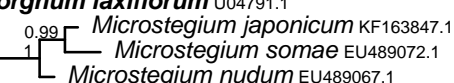

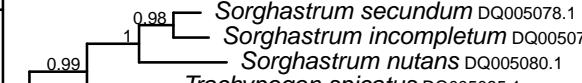

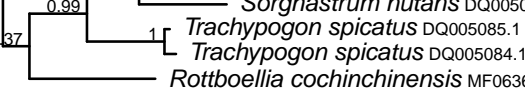

000 .

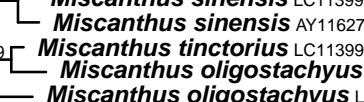

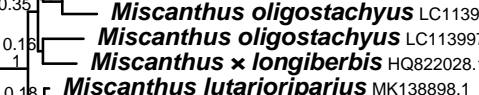

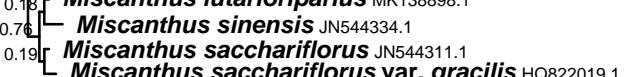

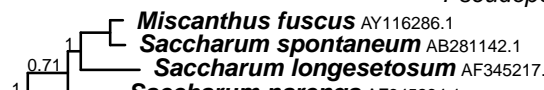

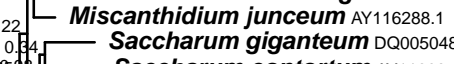

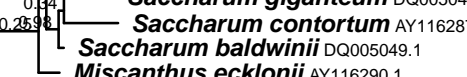

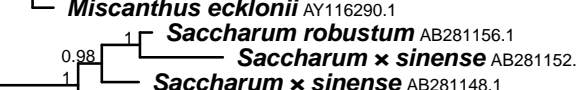

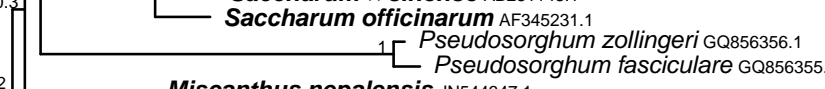

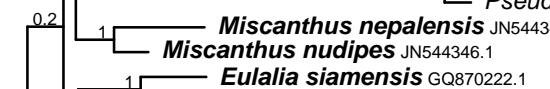

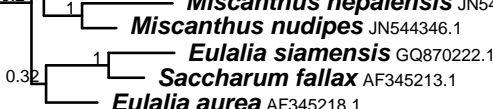

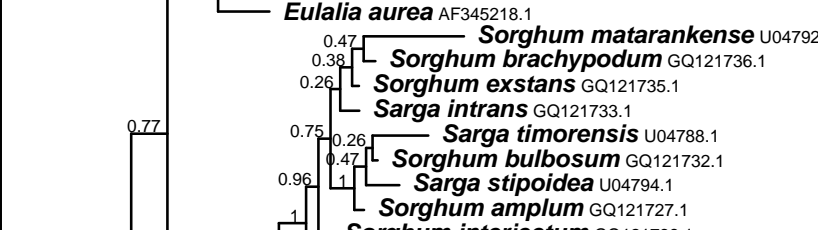

0.78

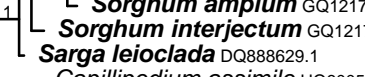

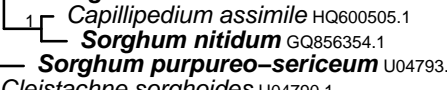

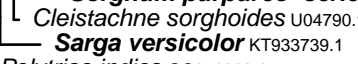

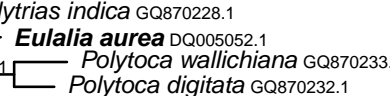

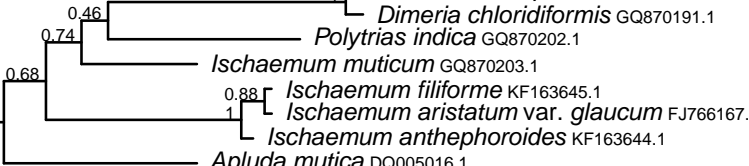

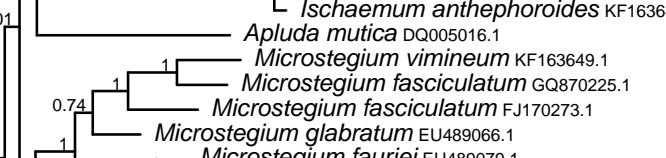

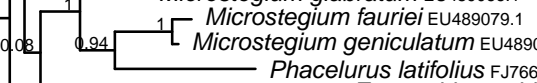

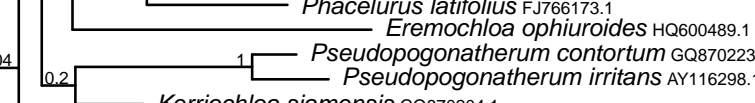

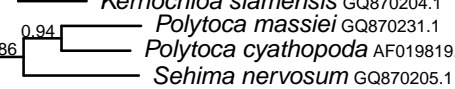

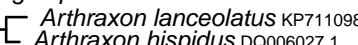

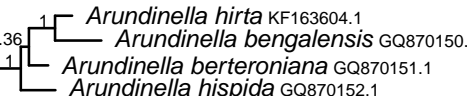

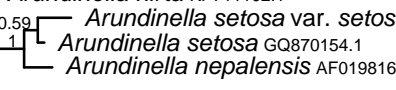




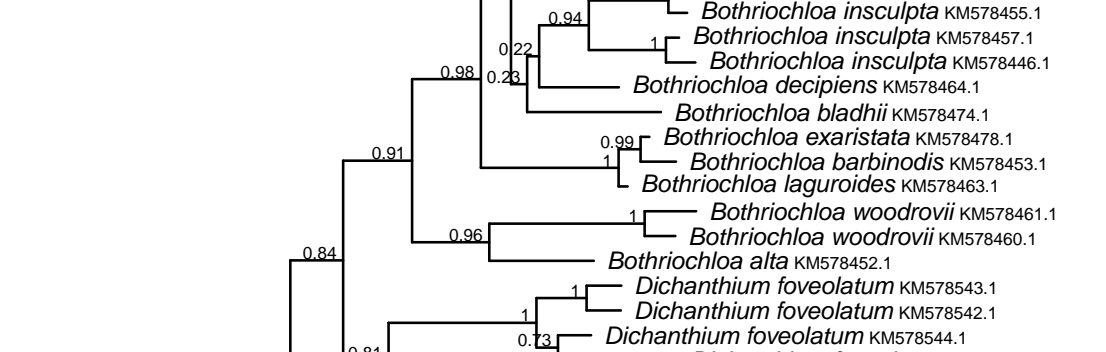

1

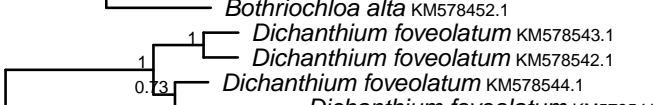

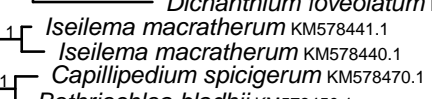

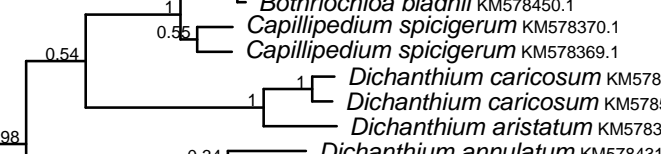

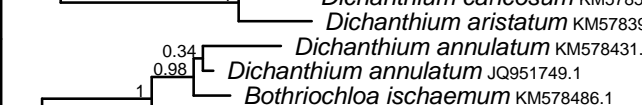

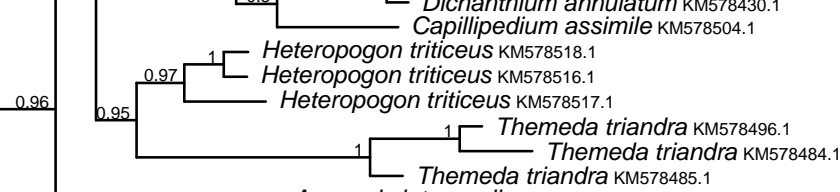

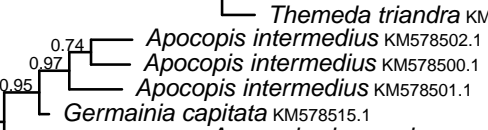

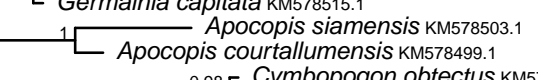
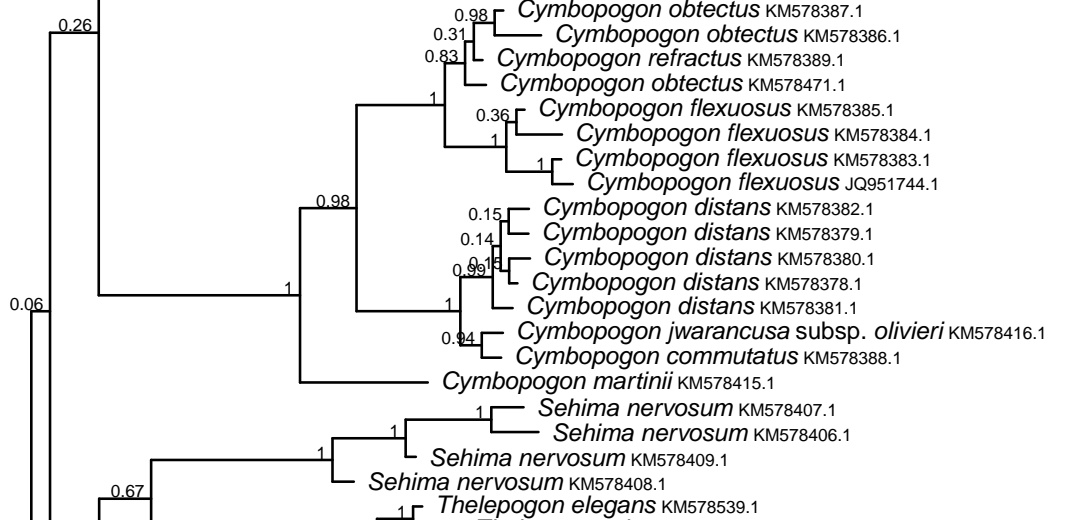

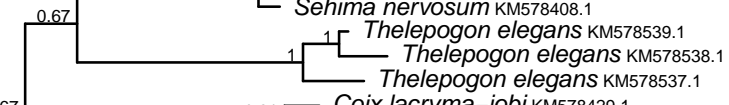

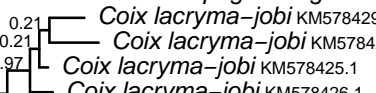

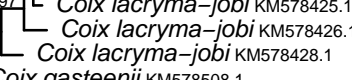

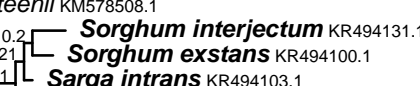

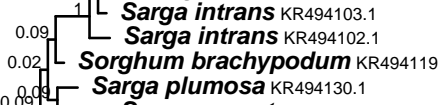

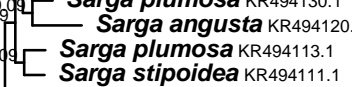

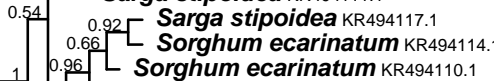

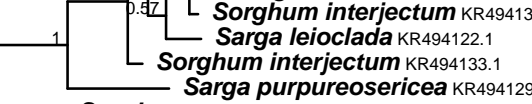

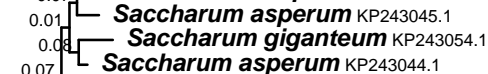

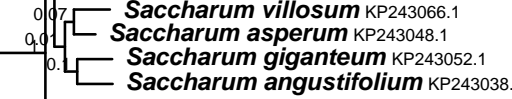

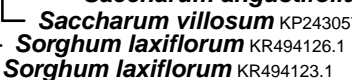

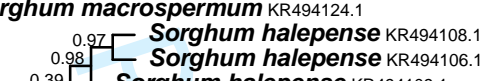

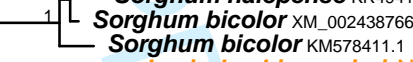

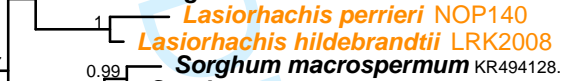

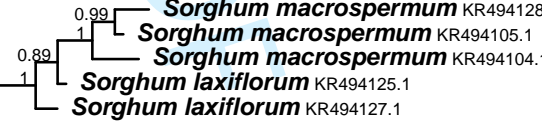

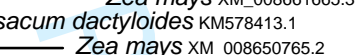

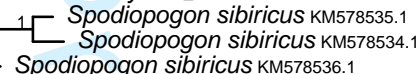

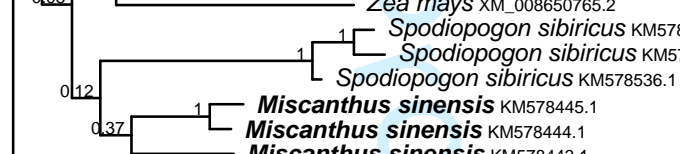

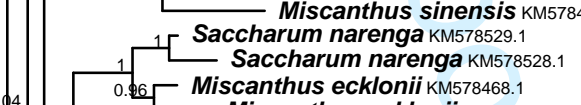

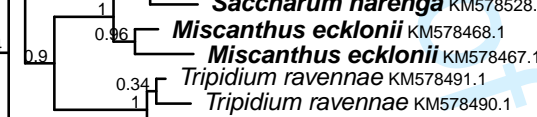

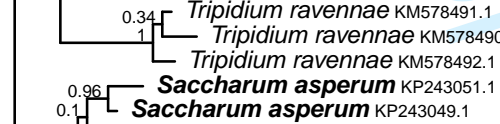

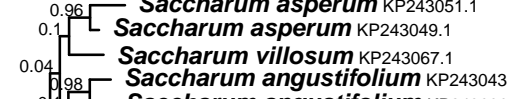

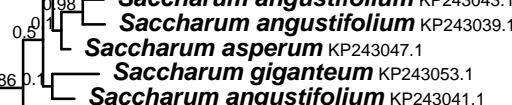

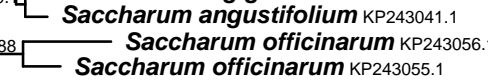

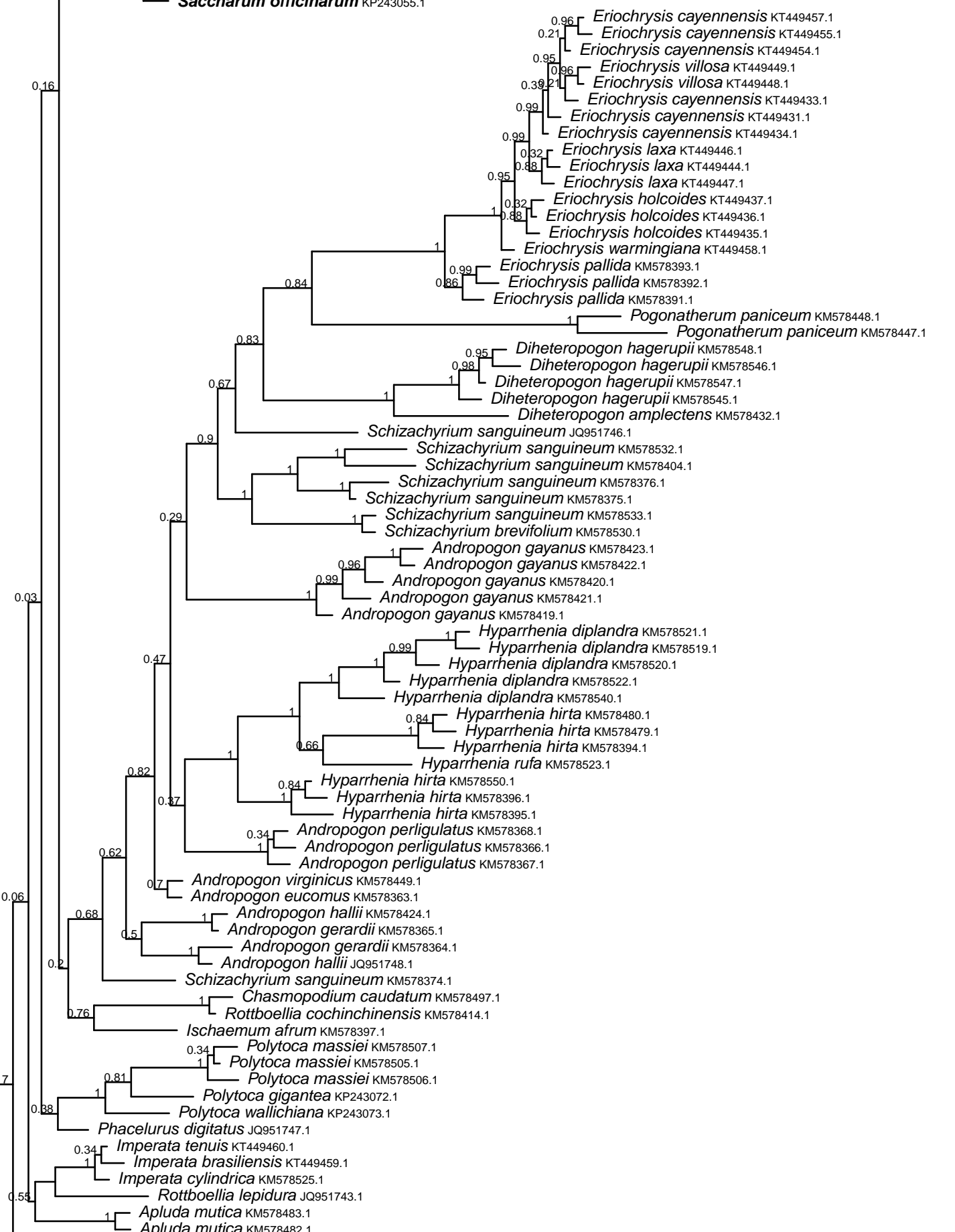

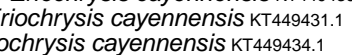

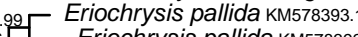

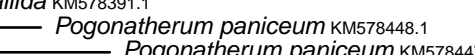

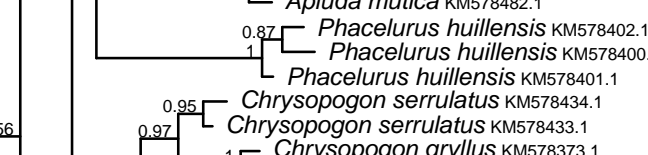

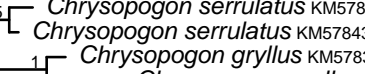

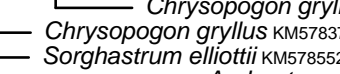

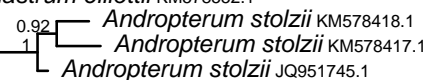

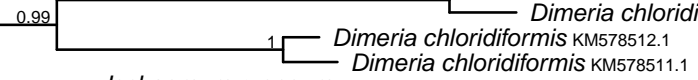

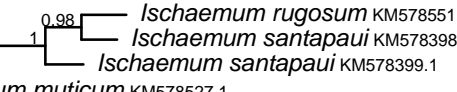




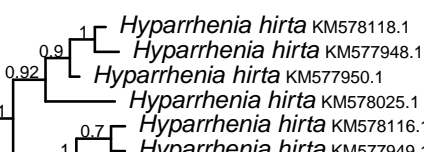

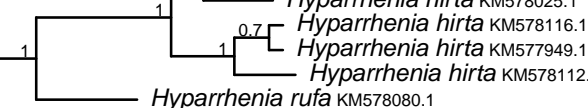

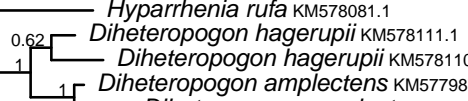

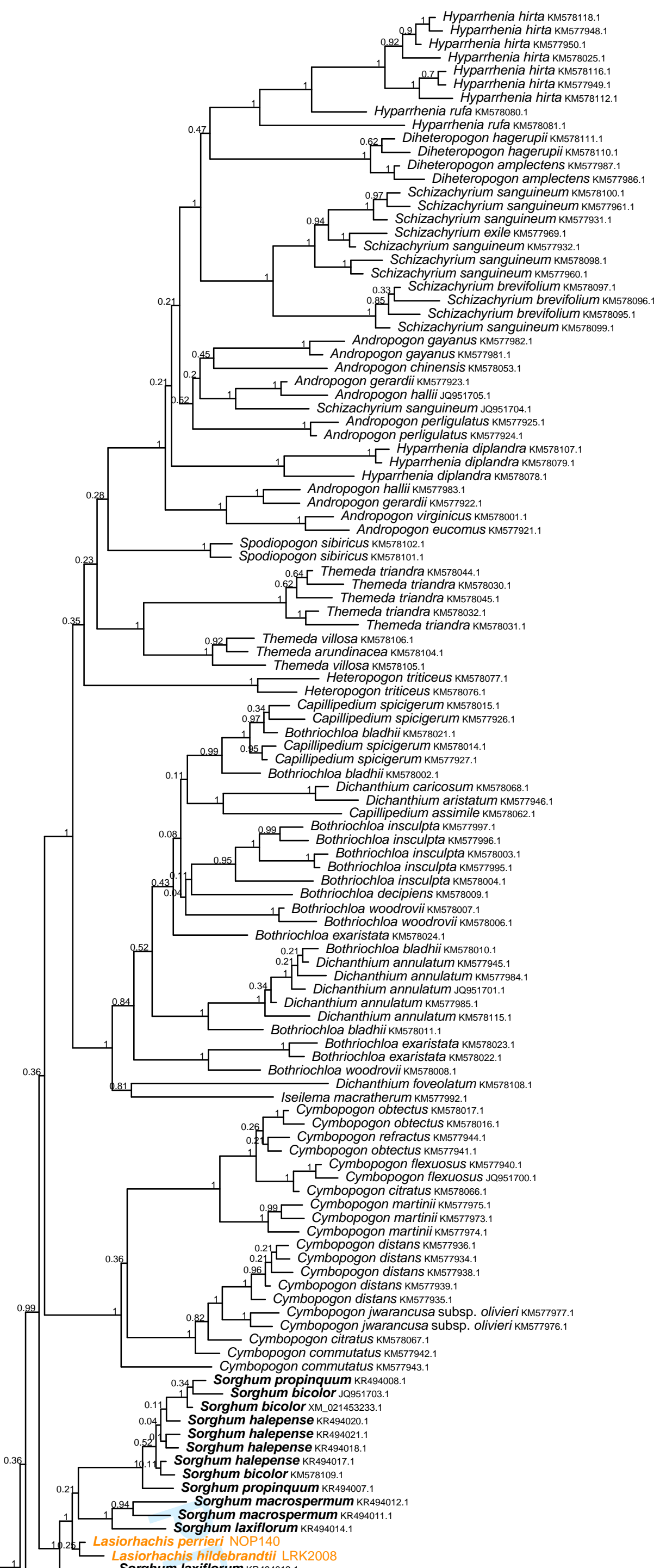

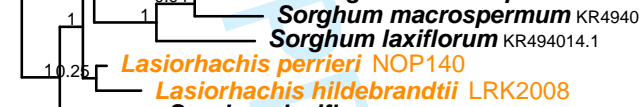

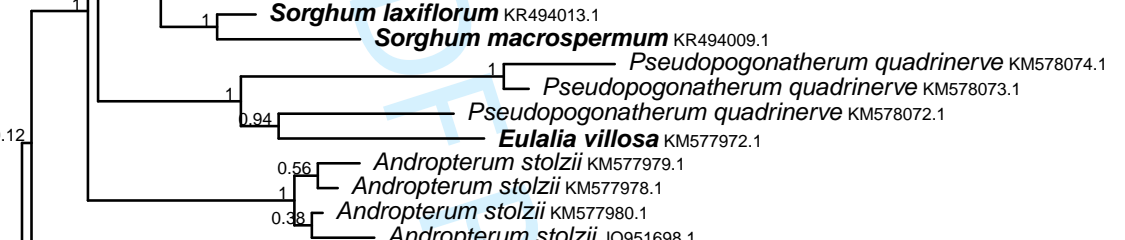

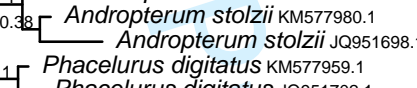

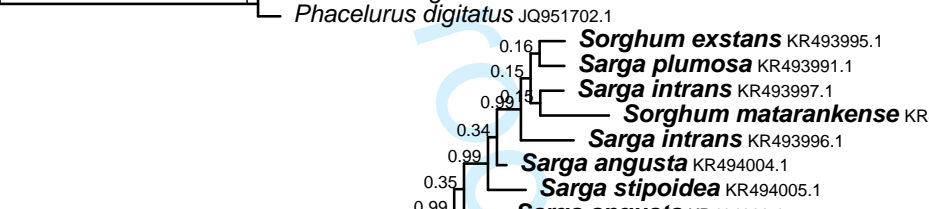

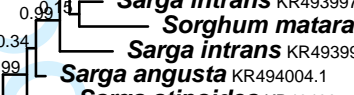

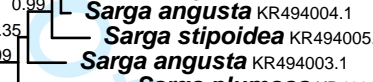

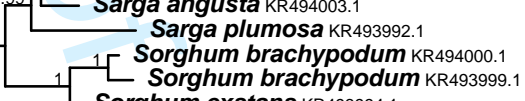

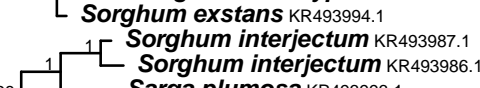

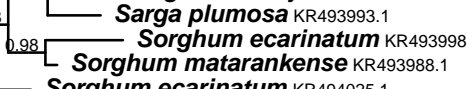

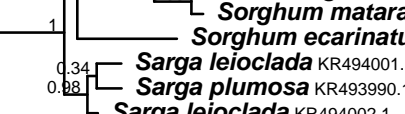

Lits

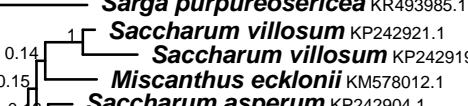

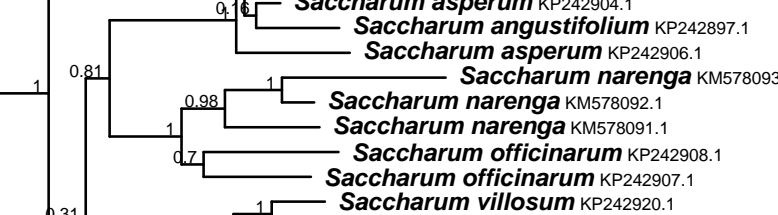

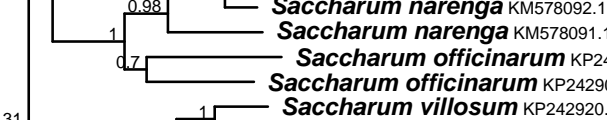

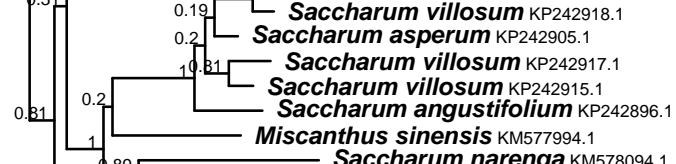

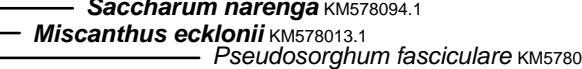

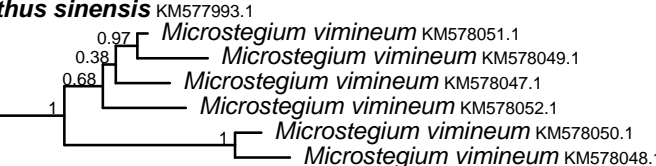

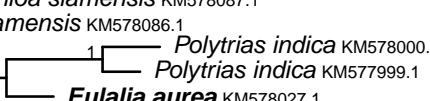

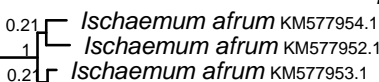

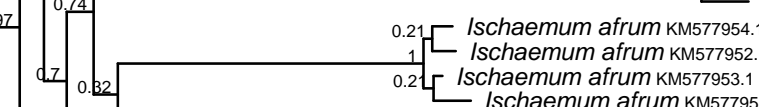

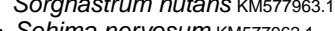

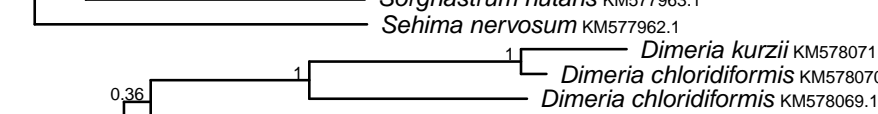

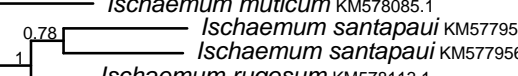

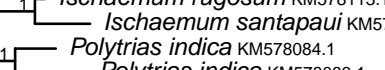

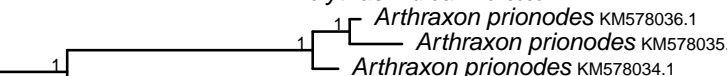

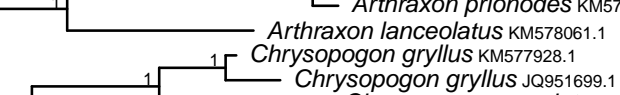

12

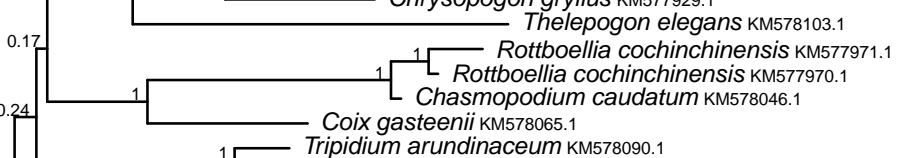

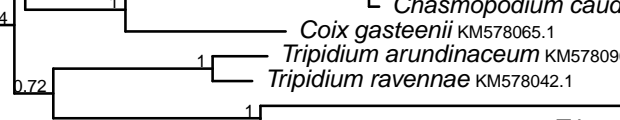

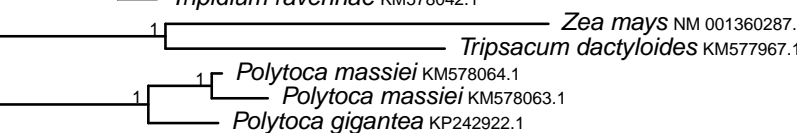

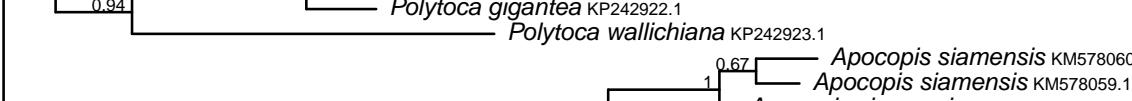

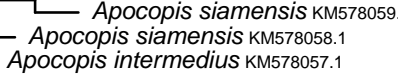

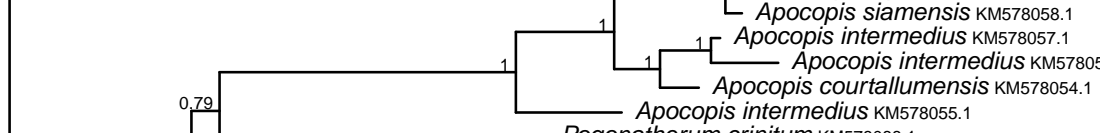

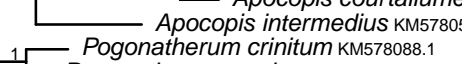

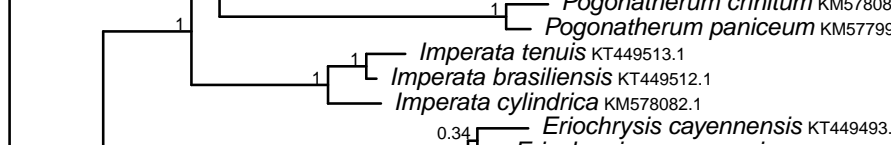

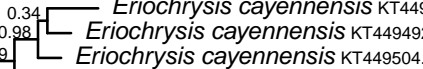

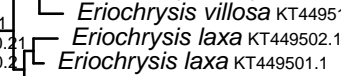

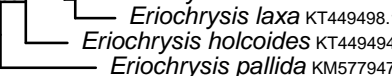

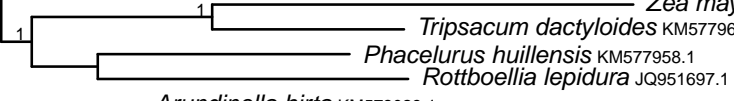

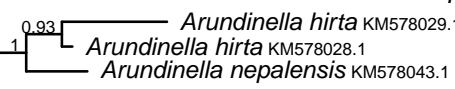




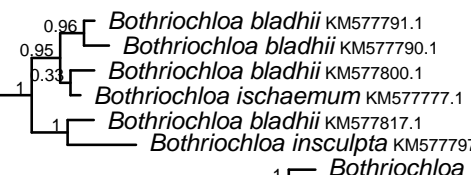

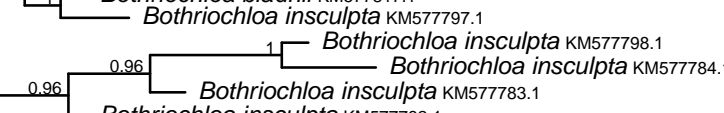

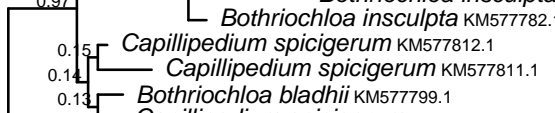

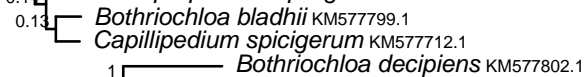

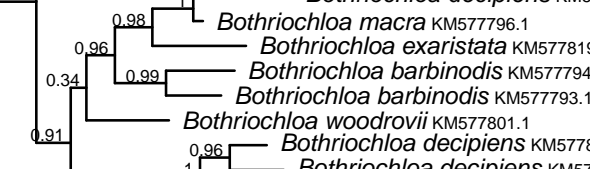

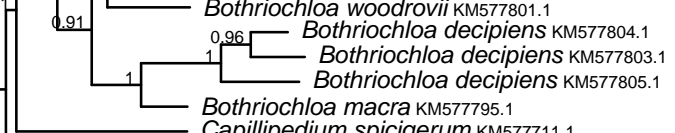

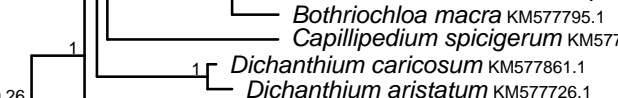

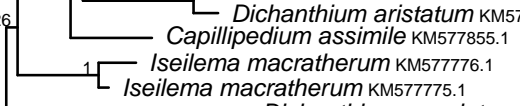

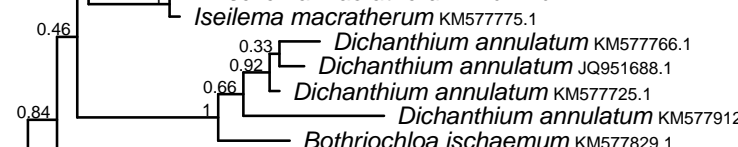

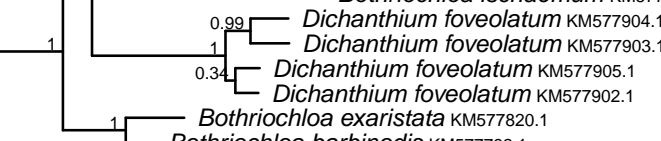

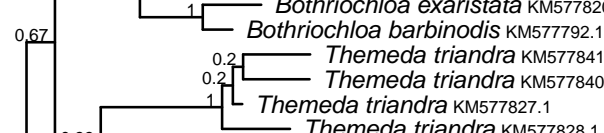

202

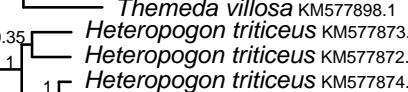

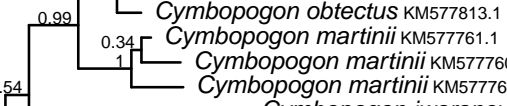

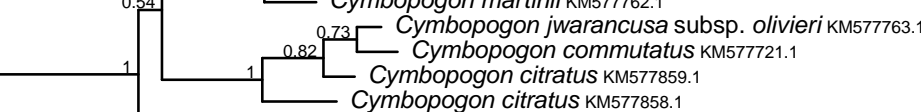

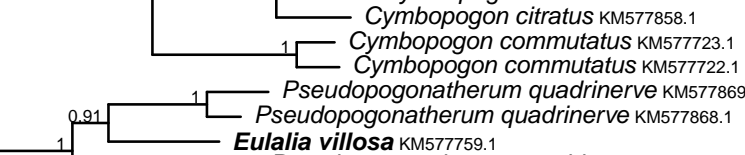

1.

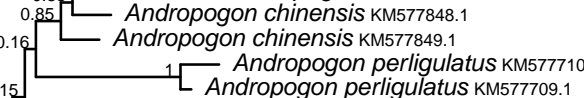

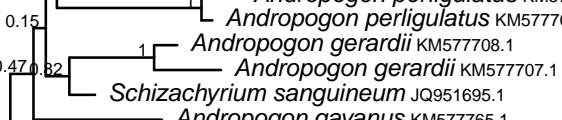

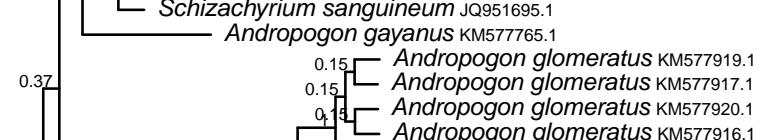

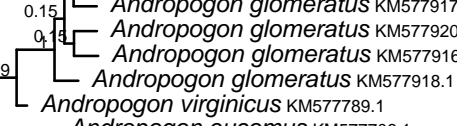

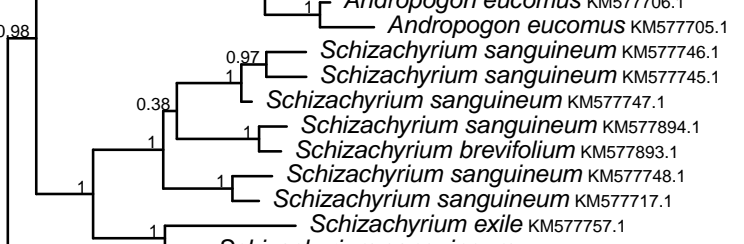

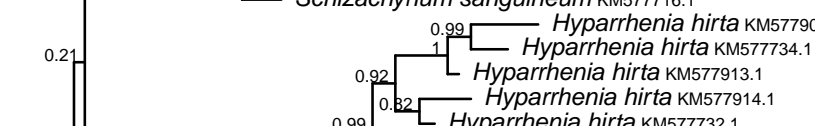

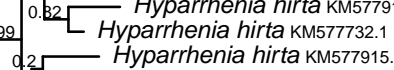

202

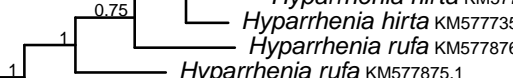

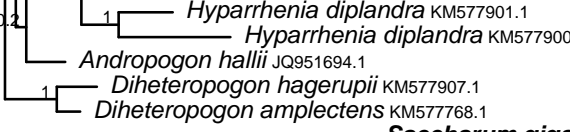

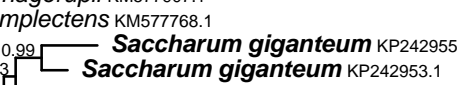

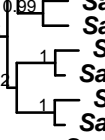

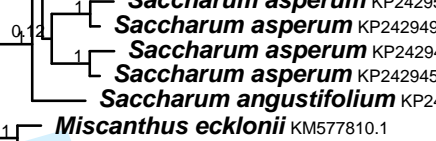

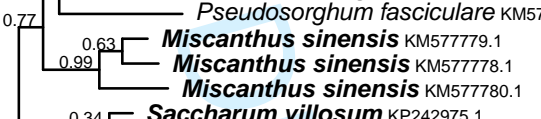

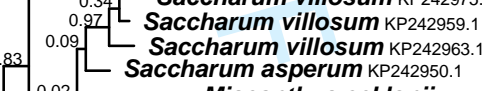

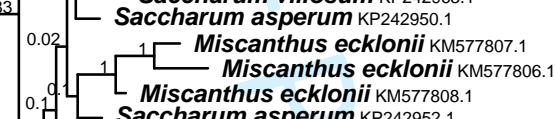

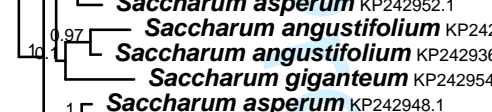

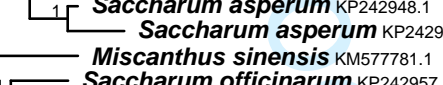

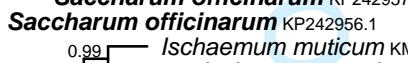

-

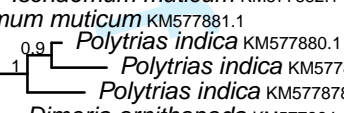

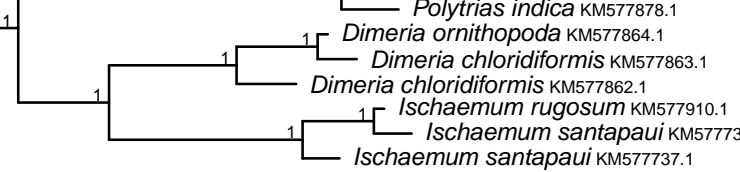

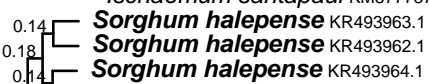

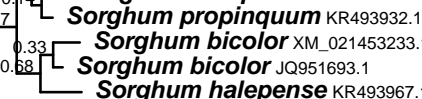

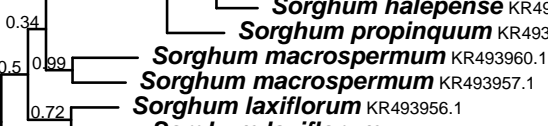

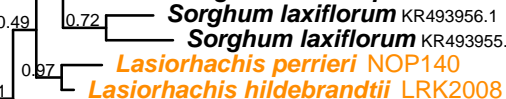

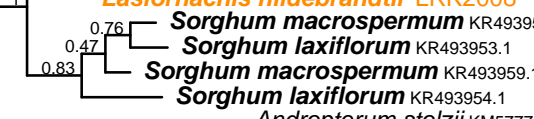

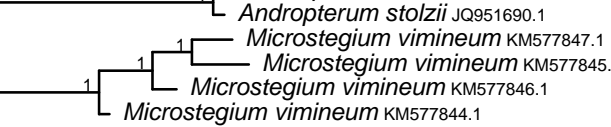

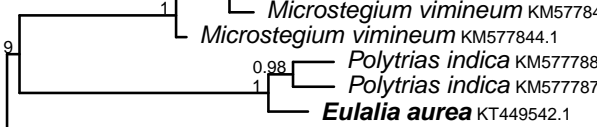

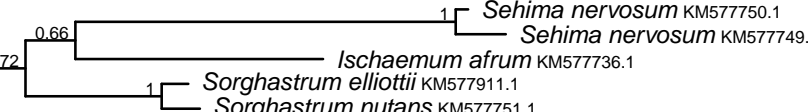

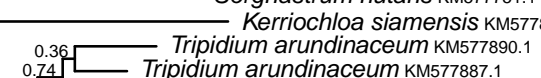

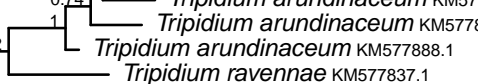

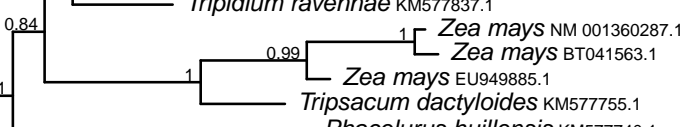

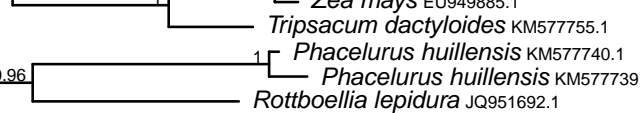

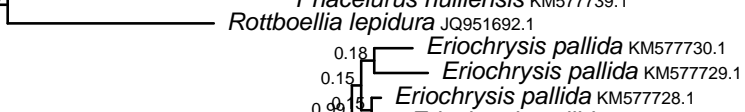

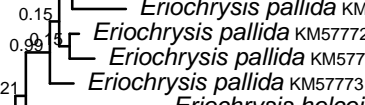

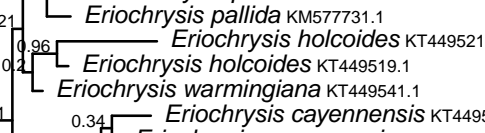

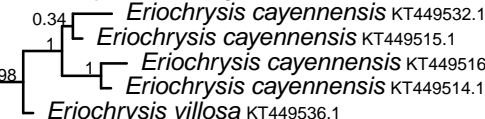

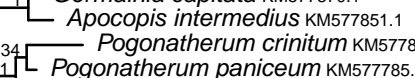

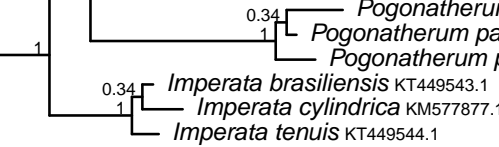

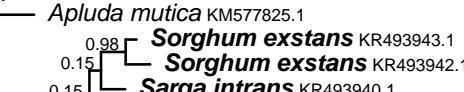

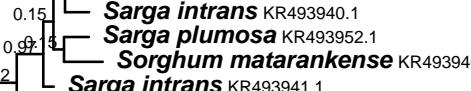

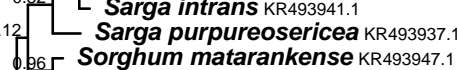

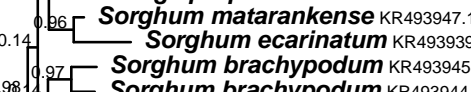

ond

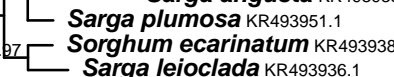

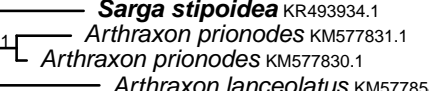

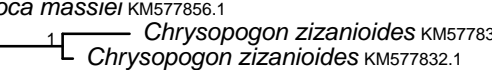

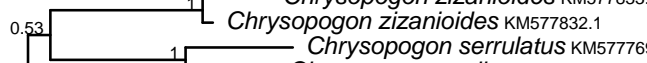

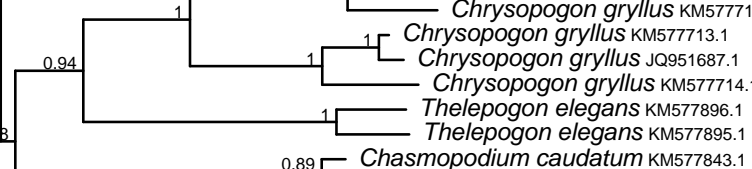

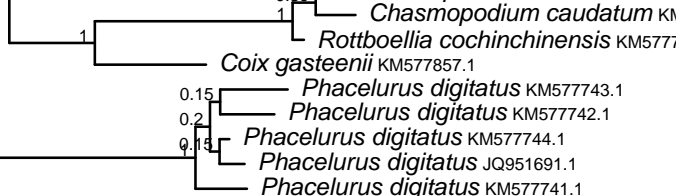

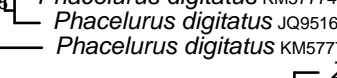




\section{F - floricaula}

0.01 subst./site

0.98 Zea mays AY789603.1

Zea mays subsp. parviglumis AY789039.1

0.15 Zea mays subsp. parviglumis AY789048.1

$0.18 \square$ Zea diploperennis AY789598.1

Zea mays subsp. parviglumis AY789036.1

Lea mays subsp. parviglumis AY789037.1

0.2 Lea luxurians AY789597.1

Zea mays subsp. parviglumis AY789043.1

0.64 18 Zea mays subsp. parviglumis AY789042.1

0.64 Zea mays subsp. parviglumis AY789044.1

0.34 0.7- Zea mays subsp. parviglumis AY789047.1

L Zea mays subsp. parviglumis AY789041.1

Z Zea mays subsp. parviglumis AY789040.1

Zea mays subsp. parviglumis AY789045

[ Tripsacum floridanum AY789601.1

Tripsacum andersonii AY789600.1 
0.07 Zea mays subsp. parviglumis EF539712.1 (1) Zea mays subsp. parviglumis EF5398719.1

0.01 subst./site 0 de- Zea mexicana FJ708436.1 $0.07 \begin{gathered}0.955 \text { Zea mays subsp. parviglumis } \\ 0.33 \text { Zerennis AF329737.1 } \\ \text { Zea diploperennis AF329736. } 1\end{gathered}$

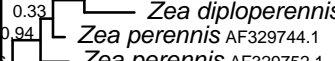
- Zea mays subsp. parviglumis EF539649.1 $0.5-5$ Zea mexicana AF079260.1 1 . 0.03 Zea mays xo3935.1

Zea mays subsp. parviglumis FJ708473.1 0.23 Z Zea mexicana FJ708427.1 Zea mays subsp. parviglamis EF539702.1 .98 - Zea mays subsp. parviglumis EF539683.1

Z Zea mays AY109531.1 0.24 Z Zea mays subsp. parviglumis 0.32 ${ }_{0.46}[$ Zea mays subsp. parviglumis EF539711.1

0.44 Zea mays XM mays AF2627643

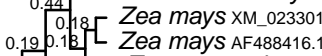

0.19. L Zea mays subsp. parviglumis EF539685.1

Zea luxurians FJ708445.1

红 Zea perennis AF 329755.11

0.88 Z Zea mays subsp. parviglumis EF539723.1

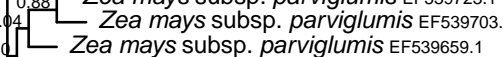

2. Z Zea mays subsp. parviglumis EF539720.1

- Zea mays subsp. parviglumis EF539696.

느 Zea mays subsp. parviglumis EF539705.1

1 - Zea perennis AF329749.1

Zea perennis AF329748.1

Zea diploperennis AF329743.

- Andropogon gayanueropogon
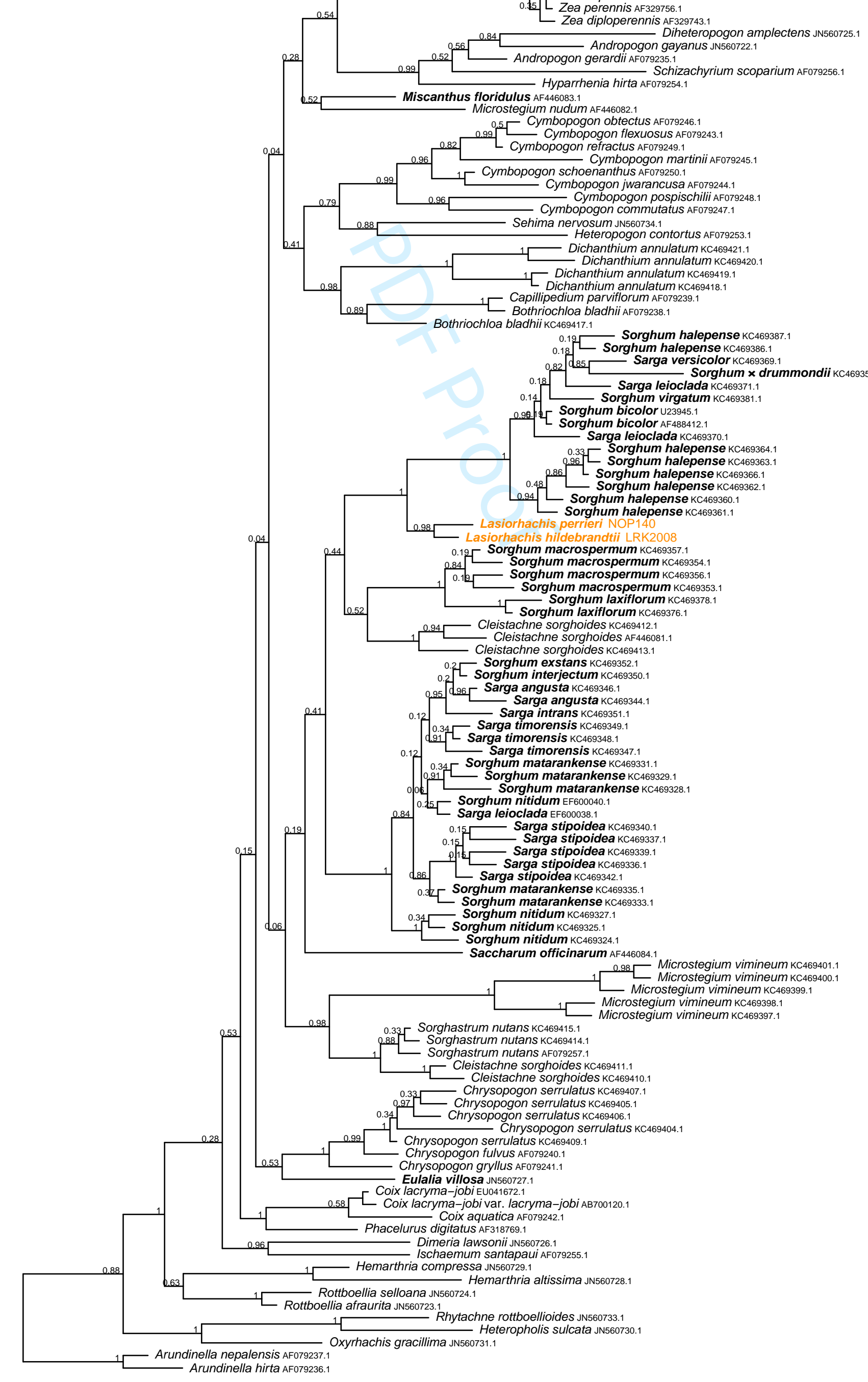


\section{$H$ - phyB}

Sorghum bicolor AY466085.1

0.13 Sorghum bicolor AF182394.1

0.13 Sorghum arundinaceum AY466097.1

Sorghum bicolor AY466090.1

0.34. [ Sorghum bicolor AY466087.1

0.4 Sorghum bicolor AY466088. 1

0.2 Sorghum Sorghum halepense AF137326.1

Sorghum arundinaceum AY466093.1

1 Sorghum arundinaceum $\mathrm{AY} 466093$.

Sorghum arundinaceum AY466098.1

Lasiorhachis perrieri NOP140

$[$ Lasiorhachis hildebrandtii $\perp$ RK2008 - Ischaemum afrum AF443812.
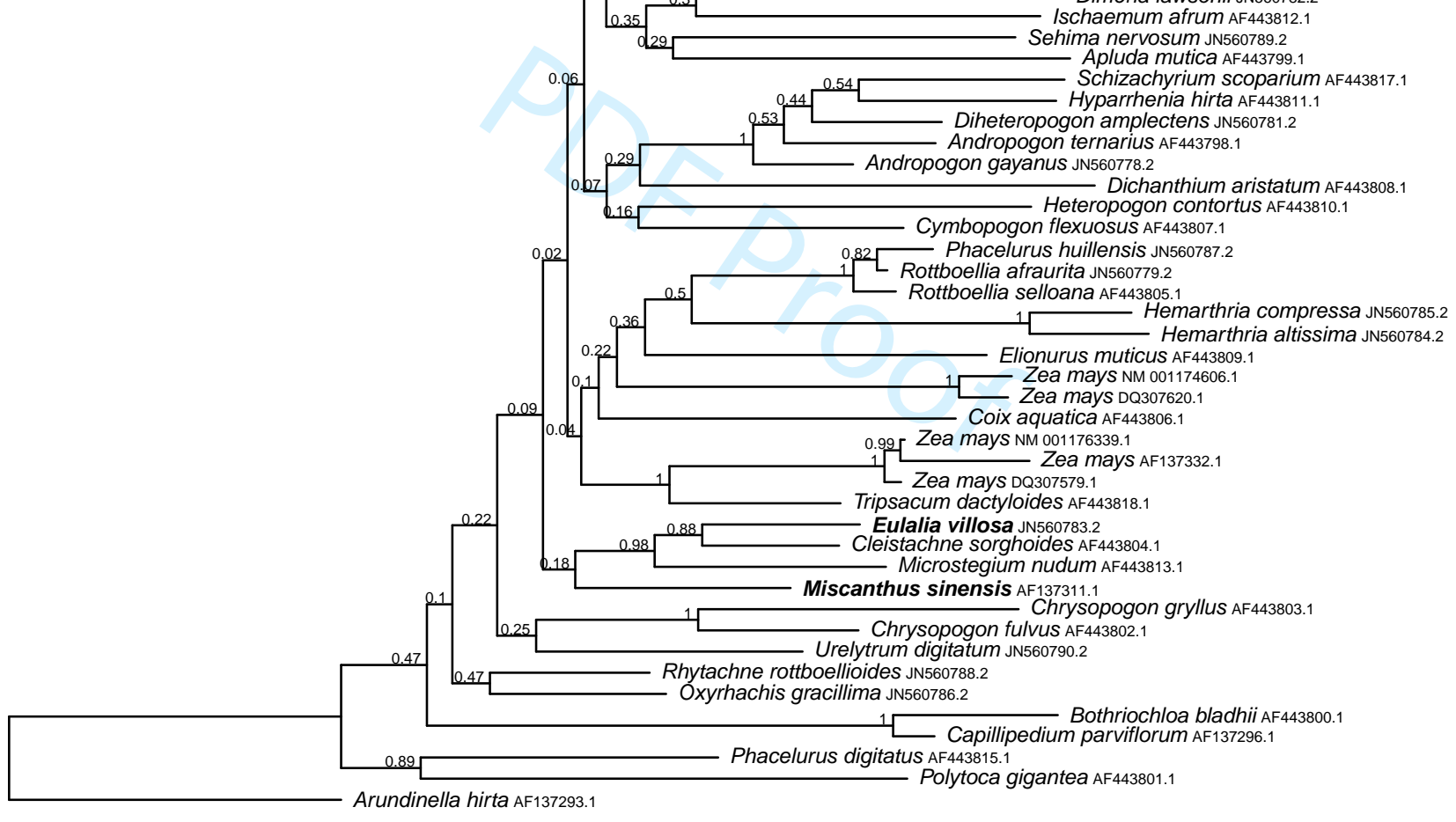

Botanical Journal of the Linnean Society 


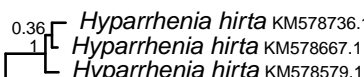

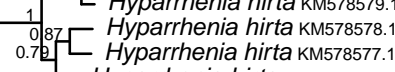

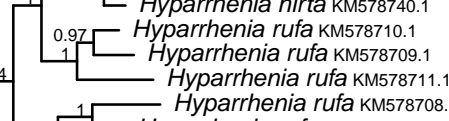

H. Hyparthenia rutak KM57870

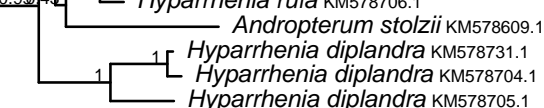

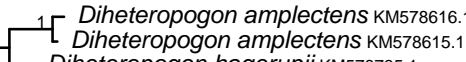

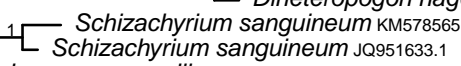

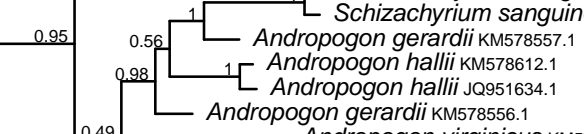

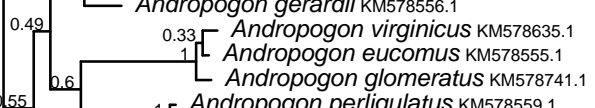

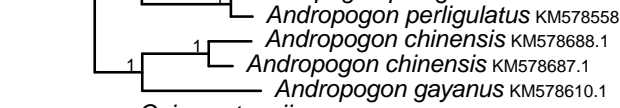

$0.0331-$ Coix gasteenii KM578695,

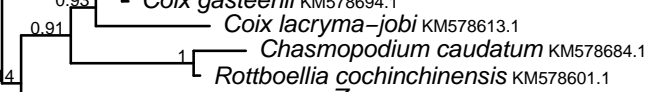

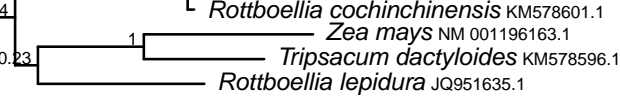

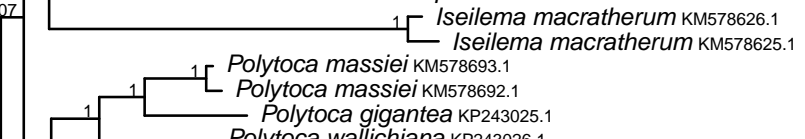

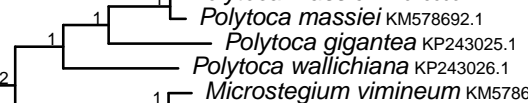

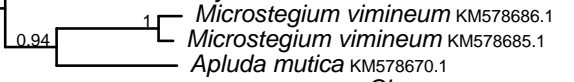

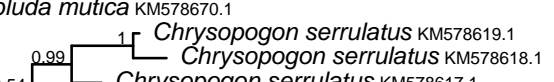

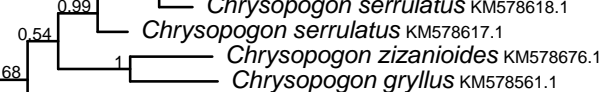

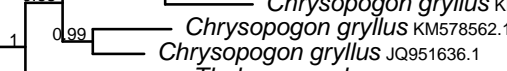

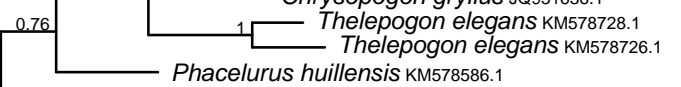

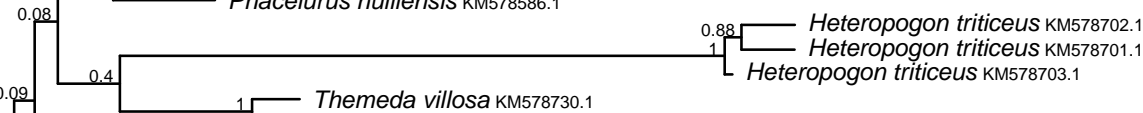

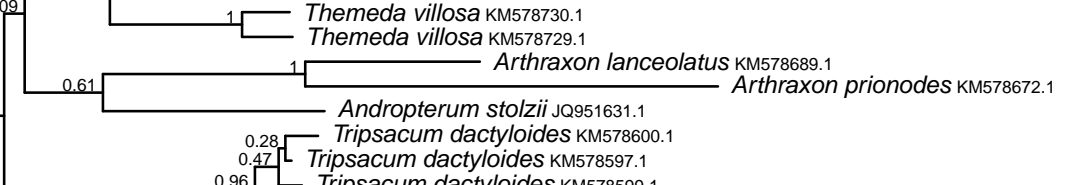

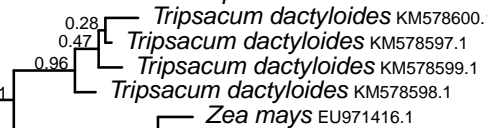

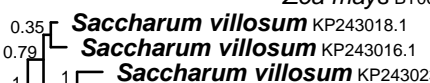

L Saccharum villosum KP 243008.

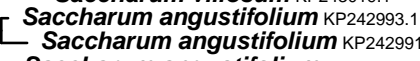

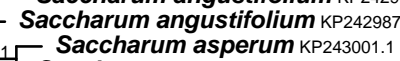

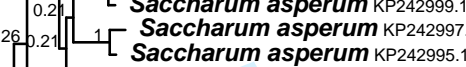

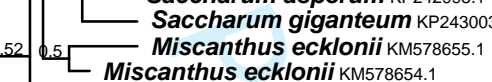

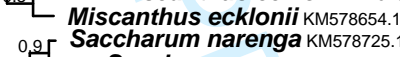

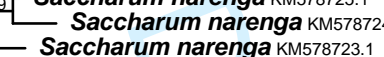

0.16 S Saccharum villos

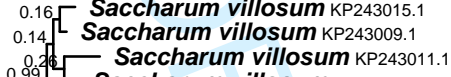

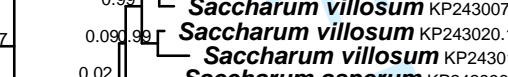

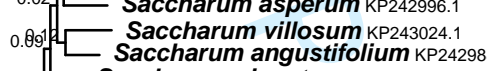

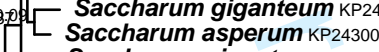

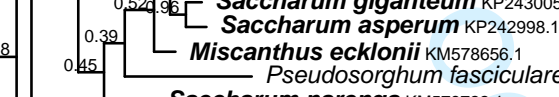

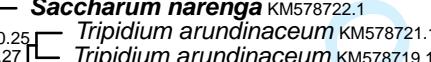

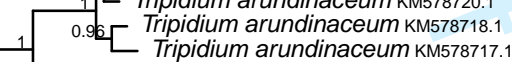

-1. Tripidium ravium arunnainaceum

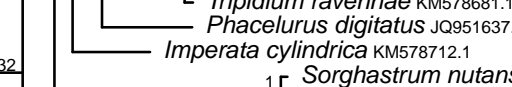

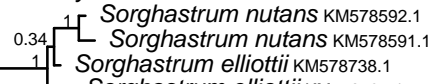

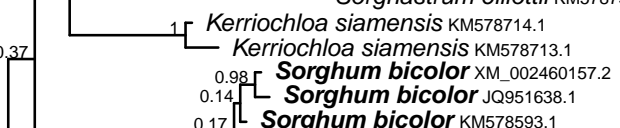

a
and

Lasiorhachis hildebrandtiil LRothriouchloa insculpta KM578644.

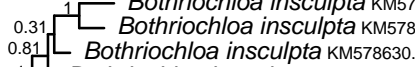

1 Bothriochloa insculpta KM5786 i

0.92 Bothriochloa bladhii KN578664.

Q.3.3. Bothriochloa ischaemum KM578

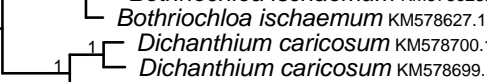

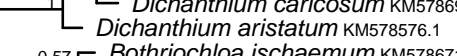

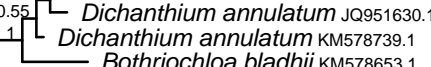

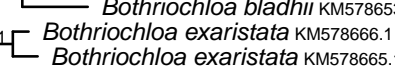

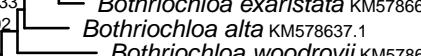

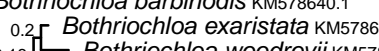

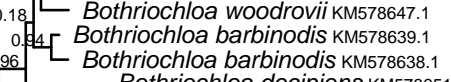

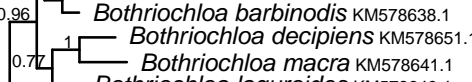

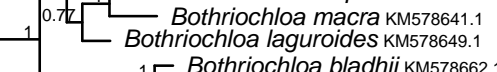

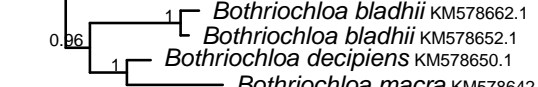

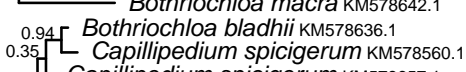

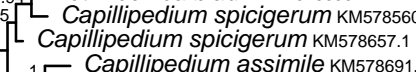

L Capillipedium assimile KM578659

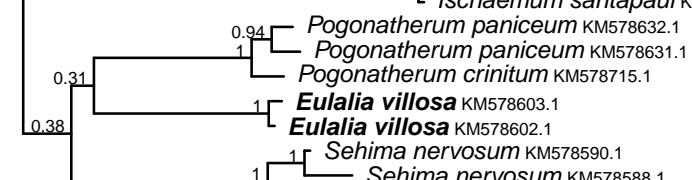

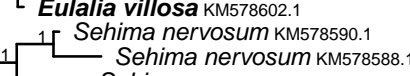

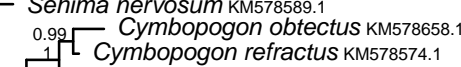

4 Cymbopogon flexuosus KM57557?

0.42 Cymbopogon citratus KN 578967.1

Cymbopogonon citratus KN578696.1

oe[ Cymbopogon citratus KM578698.1

alivierikn578008

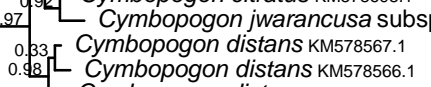

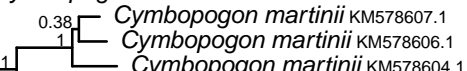

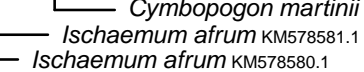

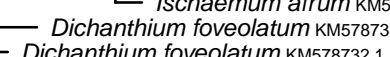

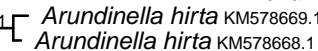

